\title{
SOLARPILOT UYGULAMASIYLA ISPARTA İLİNDE GÜNEŞ KULESİ MODELLEMESİ
}

\author{
Serhat ŞEN*,ibrahim ÜÇGÜL
}

Süleyman Demirel Üniversitesi, Fen Bilimleri Enstitüsü, Yenilenebilir Enerji ABD, Isparta, Türkiye

\begin{abstract}
Anahtar Kelimeler
Güneş Enerjisi,

Heliostat Alan,

Güneș Kulesi,

Alicl,

SolarPILOT.

Öz

Bu çalışma, özellikle heliostat aynaların alıcıya odaklanarak yüksek sıcaklıklarda enerji üretimi için çalışmalarda bulunulan Merkezi Odaklamalı Güneş Güç Sistemi veya Güneş Kulesi olarak adlandırılan sisteme ve sistem tasarımlarına farklı bakış açısı getirmek amacıyla SolarPILOT programı tanıtılmıştır. Isparta ili için günlük $10 \mathrm{MWt}$ kapasiteli, yıllık enerji üretimi gerçekleştirilecek planlamasıyla, sistem uygulanabilirliği için sistem tasarımının en önemli hesaplama parametreleri olan heliostat alan ve heliostat alanın termal gücüne bağlı alıcı ve heliostat alan yerleşimi incelenmiştir. Bu işlemler için, güneş ışınım modeli, güneşlenme modeli, sistem tasarım parametreleri, heliostat seçim kriterleri, optimizasyon simülasyonu gerçekleştirilmiştir. Bu hususların adım adım SolarPILOT uygulamasında kullanılan modeller açıklanarak, hesaplama için seçimi gerçekleştirilen model açıklamasıyla birlikte verilmiştir. Uygulama tasarım değerleri tespit edilmiş olup, uygulamanın yapılması planlanan arazinin yıllık ortalama DNI (Direct Normal Irradiation (Doğrudan Normal Işınım)) verisi tespit edilerek sistem optimizasyonu gerçekleştirilmiştir. Alan düzenlemesi gerçekleştirilerek sistem için gerekli heliostat alanı tespit edilmiştir. Yaklașık termal kayıplar belirlenerek sistem hesaplamaları tamamlanmıştır. Bulgular, güneş kulesi modelinin Isparta ili için uygulanabilir olduğunu göstermiş ve tasarım parametreleri elde edilmiștir.
\end{abstract}

\section{SOLAR TOWER MODELING WITH THE SOLARPILOT APPLICATION IN ISPARTA}

\begin{tabular}{ll}
\hline Keywords & Abstract \\
\hline $\begin{array}{l}\text { Solar Power, } \\
\text { Heliostat Field, }\end{array}$ & In this study, the SolarPILOT program has been introduced to bring a different \\
Solar Tower, & perspective to the system and system designs called Central Focused Solar Power System \\
Receiver, & or Solar Tower, where studies are carried out for energy generation at high temperatures, \\
SolarPILOT. & especially by focusing on the receiver of heliostat mirrors. The most important \\
calculation parameters of the system design for the system applicability, the heliostat & area and the receiver and heliostat area settlement depending on the thermal power of \\
the heliostat area, were examined for the province of Isparta, with a daily capacity of 10 & MWt and annual energy production planning. For these processes, solar radiation model, \\
& insolation model, system design parameters, heliostat selection criteria, optimization \\
& simulation were performed. These issues are explained step by step the models used in \\
the SolarPILOT application, together with the model description selected for calculation. & The application design values were determined, and the system optimization was \\
performed by determining the annual average DNI (Direct Normal Irradiation) data of & the land to be implemented. The heliostat area required for the system was determined \\
by field arrangement. The system calculations have been completed by determining the & approximate thermal losses. The findings showed that the solar tower model is \\
applicable for the province of Isparta and design parameters were obtained.
\end{tabular}

Alıntı / Cite

Şen, S., Üçgül, İ., (2021). SolarPILOT Uygulamasıyla Isparta İlinde Güneş Kulesi Modellemesi, Mühendislik Bilimleri ve Tasarım Dergisi, 9(4), 1302-1325.

\footnotetext{
* ilgili yazar / Corresponding author: serhatsen89@gmail.com , +90-246-211-1519
} 


\begin{tabular}{l|l|l}
\hline Yazar Kimliği / Author ID (ORCID Number) & \multicolumn{3}{|l}{ Makale Süreci / Article Process } \\
\hline S. Şen, 0000-0002-7688-9104 & Başvuru Tarihi / Submission Date & 12.10 .2020 \\
İ. Üçgül, 0000-0001-9794-0653 & Revizyon Tarihi / Revision Date & 06.08 .2021 \\
& Kabul Tarihi / Accepted Date & 15.10 .2021 \\
& Yayım Tarihi / Published Date & 20.12 .2021 \\
\hline
\end{tabular}

\section{Giriș (Introduction)}

Amerika Birleşik Devletleri (ABD) Enerji Bakanlığı'nın (DOE) destekleriyle, Ulusal Yenilenebilir Enerji Laboratuvarı (NREL) tarafından ücretsiz olarak System Advisor Model (SAM) programıyla yenilenebilir enerji sektöründe uygulama modellemeleri üzerine programlama gerçekleştiren, dünyada uygulama noktasında en fazla gerçekleștirilen 10 sistem için modelleme dizaynı gerçekleştirmiş olup, gün geçtikçe yeni versiyonlarıyla hem yeni modeller eklemekte, hem de mevcut modellerini geliştirmektedirler (SAM, 2020; NREL, 2020).

Bu uygulamaları gerçekleștirirken, bünyesindeki modellemeler için daha spesifik işlemlerin gerçekleștirilebilmesi amacıyla her model için ayrı program oluşturmaktadır. Bu hususta güneş kulesi hesaplarıyla ilgili olarak SolarPILOT programı geliștirilmiştir. Orijinal ismi "The Solar Power Tower Integrated Layout and Optimization Tool" olan SolarPILOT, Türkçe olarak "Güneş Enerjisi Kulesi Entegre Yerleşim ve Optimizasyon Aracı" olarak adlandırılmaktadır (NREL, 2020).

SolarPILOT, dünyada aktif olarak elektrik enerjisi üretimi gerçekleștiren güneş kulelerinin hesaplama parametrelerini kullanarak, geliştirdiği modelleme sayesinde, güneş kulesi tesisleri için ön fizibilite imkânı sunmaktadır. Bu sayede güncel güneş kulesi hesaplamalarında ilk aşama olarak, heliostat konumlandırma, hedefleme, uygulama arazi sınırlandırması, maliyet analizi vb. hususların incelenmesinde hem iş gücünden hem de zamandan tasarruf edilmesini sağlamaktadır.

Bu çalışmada, ülkemizde güneş kulesi uygulamasının heliostat alan yansıtma verimliliği, uygulama için gerekli alan ve uygulanabilinirliğinin tespiti için SolarPILOT uygulamasını kullanarak, gerçekleștirilen her adım ve modül aşama aşama açılanarak, Isparta ilinde belirlenen alan üzerinde sistem hesaplamaları ve uygulanabilinirliği ile ilgili araştırmalar gerçekleştirilmiş ve uygulamayı kullanmak isteyen araştırmacılara yardımcı olmayı hedeflemektedir. Programda maliyet analizi (markets, costs) hesaplamaları bulunmakta olup, uygulama esasında öncelikli olarak sistem tasarımı hesaplamaları olmasından dolayı, maliyet analizi işlemleri gerçekleştirilmemiştir.

\section{2- Uygulama Yapılması Planlanan Alanın Belirlenmesi (Determination of the Area Planned for Implementation)}

Elektrik Enerjisi üretim tesis tasarımlarında ilk olarak belirlenmesi ve incelenmesi gereken husus, kurulması planlanan tesisin uygulama alanıdır. SolarPILOT uygulamasında kullanıcılara, güneş kulesi sistemlerinin aktif olarak uygulama alanlarının güneş enerjisi verileri sistemde kayıtlıdır. Bu kayıtlar incelendiğinde bașta Amerika'nın çoğu eyaleti olmak üzere Birleşik Arap Emirlikleri, İspanya, Portekiz, Peru, Kenya, Hindistan, Honduras, Guatemala, Etiyopya, El Salvador, Mısır, Küba, Çin, Şili, Kanada, Brezilya ve Avustralya ülkelerinde uygulama arazilerinin verileri mevcuttur.

Programda, uygulaması planlanan alan verileri olmaması durumunda, Avrupa Komisyonu (European Commission (EU)), Ortak Çalışma Merkezi (Joint Research Centle (JRC)) tarafından, Fotovoltaik Coğrafi Bilgi Sistemi (Photovoltaic Geographical Information System (PVGIS)) bilgi merkezleri sayesinde, verileri mevcut olmayan Avrupa, Afrika, Arap yarımadası bölgelerini de kapsayan yaklașı 150 ülkenin güneș verilerini belirtilen bilgi merkezlerinden elde ederek, SolarPILOT programında ekleyerek kullanmak mümkündür (European Commission, 2019).

Uygulama alanının güneş verileri, Fotovoltaik Coğrafi Bilgi Sistemi" tarafından alınarak sisteme eklenilerek seçilmiştir. (Şekil 1.)

Uygulama alanı ve sistem kapasitesi olarak, Isparta ili, Süleyman Demirel Üniversitesi, Doğu Kampüsü, Teknokent yolu üzerinde mevcut boş bulunan arazi üzerinde günlük $10 \mathrm{MWt}$ kapasiteli, yllık enerji üretimi incelenmiştir. 


\subsection{Uygulama Bölgesi İklimsel Verileri (Climate)}

\subsubsection{Uygulama Alanı ve Verilerinin Belirlenmesi (Determination of the Area Planned for Implementation)}

Uygulaması gerçekleștirilecek alanın verilerini, program verilerine ekledikten sonra uygulama arazisi lokasyonun seçilmesiyle, veri girişi otomatik olarak gerçekleştirilir (Şekil 1.).

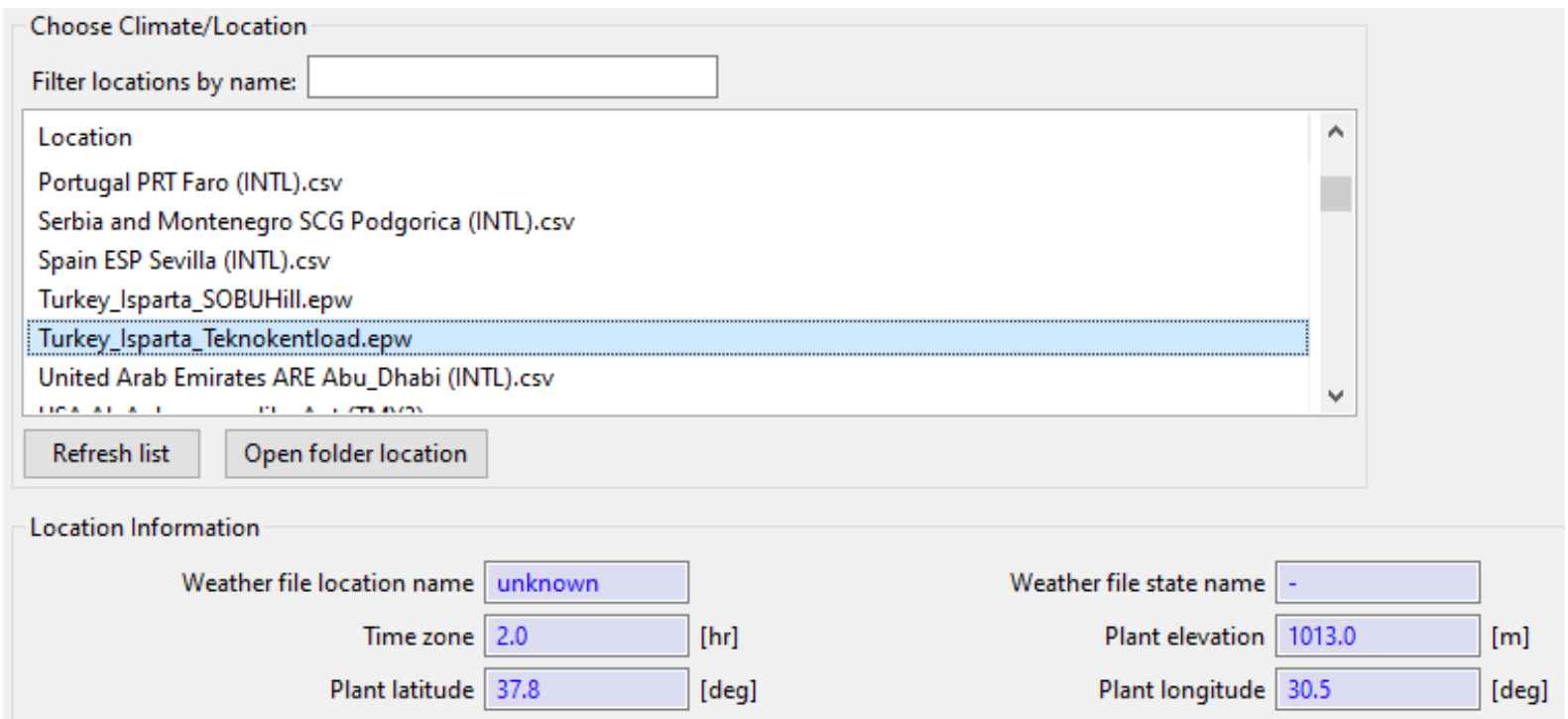

Şekil 1. Uygulama Alanı Lokasyonu ve Konum Verileri (Application Area Location and Location Data)

Konumum seçilmesiyle, "Fotovoltaik Coğrafi Bilgi Sistemi" tarafından veri girişi sayesinde otomatik olan doldurulan veriler gözükmektedir. Weather file location name, uygulama alanının özel bir ismi mevcutsa onu belirtilmesi amacıyla kullanılmaktadır. Weather file state name, uygulama arazisinin bulunduğu ülkeyi göstermektedir. Time zone olarak adlandırılan alan Greenwich Ortalama Zamanı(Greenwich Mean Time(GMT))nı ifade etmektedir. Plant latitude, uygulama gerçekleștirilecek alanın enlemini, plant longitude uygulama alanının boylamını belirtmektedir. Plant elevation, uygulama alanının deniz seviyesinden yüksekliğini ifade etmektedir. 2018 yılında gerçekleștirilen Cumhurbaşkanlığı Kararnamesi neticesinde GMT + 03:00 kalıcı saat dilimine geçilmiş olup, veri sisteminde ülkemizin kalıcı saat dilimi güncellemesi gerçekleștirilmemiştir.

Uygulama alanı verilerimiz, yaklaşık olarak $37,8^{\circ}$ enleminde $30,5^{\circ}$ boylamında ve deniz seviyesinden $1013 \mathrm{~m}$ yüksekliktedir.

\subsubsection{Uygulama Alanı Hava Koşulları Modelleri (Application Area Weather Conditions Models)}

Uygulama lokasyonunun belirlenmesinin ardından Şekil 2.'de belirtilen hava şartlarının (atmospheric conditions) belirlenmesi gerekmektedir. Bu kriterler uygulama alanının, güneş ışınımının, güneşlenme modellerinin ve heliostat aynalardan güneş kulesine yansıtılan güneş ışınlarının, atmosferik sebeplerden ötürü ışınım azalmaları ile ilgili hesaplamaları gerçekleștirmektedir.

Uygulama alanı için ilerleyen aşamada, güneş şeklinin özellikleri modeli (sunshape model), güneşlenme modeli (insolation model) ve atmosferik zayıflama model (atmospheric attenuation model)leri açıklanarak sistemsel seçimleri gerçekleștirilmiştir. 


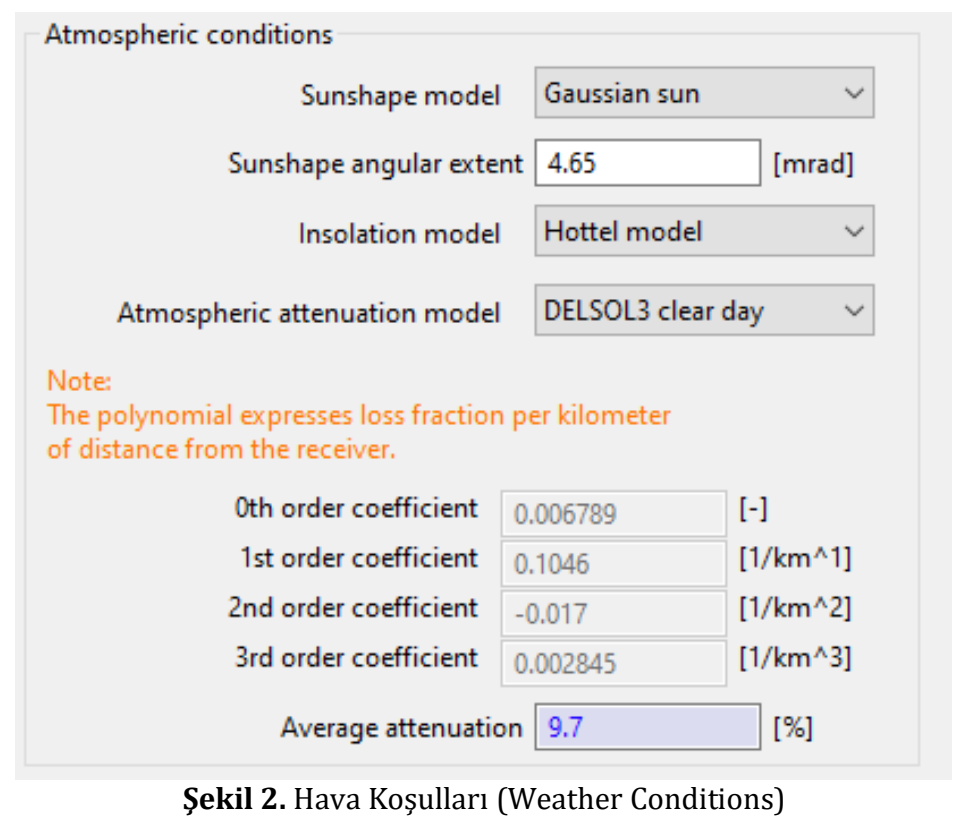

\subsubsection{Güneș Işınım Şekli Modelleri (Sunshape Model)}

Güneş ışınımı şekli, güneşin görünen şekli, daha teknik olarak, güneşin merkezinden açısal yer değiştirmenin bir fonksiyonu olarak akı yoğunluğunun profili olarak tanımlanır (Şekil 2.) (NREL, 2018; Lopez, 2016).

Programda güneş ışınımı şekli için mevcut modeller;

- Pillbox sun (Pillbox Güneş Modeli)

- Gaussian sun (Gauss Güneş Modeli)

- Limb- Darkened sun (Limb-Darkened Güneş Modeli)

- Point sun (Nokta Güneş Modeli)

- Buie CSR (Buie Güneş Modeli)

- User Sun (Kullanıcı Güneş Veri Girişi)

hesaplama için mevcuttur.

\subsection{Pillbox Güneş Modeli (Pillbox Sun)}

Pillbox Sun modeli; güneş'i, güneş ışınımının açısal bir dağllımı olarak modelleyen ve güneşin etrafında çevrelenen güneş ışınımına bir yaklaşımdır. Pillbox modellemesi, diğer modellemelere göre hesaplaması daha basittir. Güneşin, belirli bir yarım açının güneş'in merkezinden bir yön konisi üzerinde sabit radyasyon ile sabit bir ışık kaynağı olarak görür ve daha yüksek açılarda sıfıra düşer, bu da açısal dağılımının sabit olduğu anlamına gelir. Pillbox modelinde radyasyonun dağılımı eşit kabul edilmektedir (Lopez, 2016; Cole ve Gottschalg, 2015).

\subsection{Gauss Güneș Modeli (Gaussian Sun)}

Gaussian modeli; güneș șeklinin açısal genişlik değerine eșit standart sapmaya sahip güneș merkezli bir gauss (standart normal) dağılımıdır. Bu model sınırlı doğrulukla bir yaklaşım olmasına rağmen, güneş şeklinin ilgilenilen tasarımlar üzerindeki etkisini parametrik olarak uygulamak için kullanılmaktadır. Havanın hem açık hem de bulutlu durumunda yüzeydeki anlık ve entegre güneş radyasyonu değerlerini hesaplamaktadır. Yerleșim ve optimizasyon hesaplamalarında kullanım için ideal bir modeldir (NREL, 2018; Kamada vd., 1986; System Advisor Model, 2020).

\subsection{Limb-Darkened Güneș Modeli (Limb-Darkened Sun)}

Güneşin dış çevresi daha düşük bir yoğunlukta gözlemlenildiğinde, güneş merkezinden daha koyu görünür. Güneşin merkezinden, güneşin dış çevresinde görünür dalga boylarındaki yoğunluğun azalması dış çevresinde koyulaşır. Bu model, güneş yoğunluğunu, aşağıdaki denklemde gösterildiği gibi, güneşin sentroidinden açısal mesafenin bir fonksiyonu olarak belirlenmektedir (NREL, 2018; Ramadevi, 2020): 


$$
\emptyset(\theta)=1-0,5138\left(\frac{\theta}{0,00465}\right)^{4}
$$

Burada $\emptyset(\theta)$, yer değiştirme açısının bir fonksiyonu olarak güneşin yoğunluk profili, $\theta$ ise güneşin sentroidinden yer değiştirme açısıdır.

\subsection{Nokta Güneş Modeli (Point Sun)}

Nokta güneş modeli; güneşi, tüm güneşlenmenin tek bir sonsuz küçük bir noktadan kaynaklanıyormuş gibi modelleyen güneş ışınımına bir yaklaşımdır. Güneşlenmenin uzamsal dağılımı nokta kaynağı yaklaşımında dikkate alınmaz, bu nedenle açısal dağılımlar göz ardı edilir ve güneş ışını tek bir noktadan yayılmak üzere modellenir. Daha geniş bir açısal dağılım göz önüne alındığında, Pillbox yaklaşımında Point Sun yaklaşımından daha doğru olacaktır (Cole ve Gottschalg, 2015).

\subsection{Buie Güneş Modeli (Buies CSR)}

Buie güneş modeli; güneşi ve güneşin etrafındaki ışın halkası (circumsolar aureole) enerjisini dikkate almaktadır. Buie, şeklinin daha gerçekçi bir model olduğunu fark etmek önemlidir, çünkü hem güneşi hem de güneşin etrafındaki ışın halkası dikkate alınmaktadır. Buie şekli için, güneşten gelen toplam enerjinin yüzdesi olarak ifade edilen, güneșin çevresinden gelen enerji olan Güneş Çevresi Oranı (Circumsolar Ratio (CSR)) değerlendirilmelidir (Lopez, 2016).

\subsection{Kullanıcı Güneş Veri Giriși (User Sun)}

Uygulama gerçekleştirilecek alanın spesifik olarak güneş ışınlarının veri girişleri ile modelleme imkânı sunmaktadır.

6 model incelendiğinde Pillbox modeli hesaplamalar için ideal bir durumdur. Gaussian modeli hassas olup, hava şartlarında anlık ve entegre güneş radyasyonu değerlerini hesaplama imkânı sunması, çalışmalar için ideal bir modeldir. Limb-Darkened, Point ve Buies CSR modelleri ideal ve hassas ölçümler için uygulama imkânı mevcut olup, Gaussian modelinin uygun optimizasyon imkânı mevcut olmasından dolayı, bu çalışmanın sistem hesaplamalarında “Gaussian Sun (Gauss Güneș Modeli)” uygulaması tercih edilmiştir (Şekil 2.).

Gaussian modeli seçildiğinde sistem tarafından güneşin yıllık ortalama açısal genişliği verisi istenilmektedir. Güneş merkezindeki radyasyon yoğunluğunun, güneş ışığından uzaklıktaki açısal sapmadaki radyasyon yoğunluğuna eşdeğer olduğu düşünülür. Bu değer “4,65 mrad'dir” (Şekil 2.) (Wang vd., 2020).

\subsubsection{Güneşlenme Modelleri (Insolation Model)}

Güneş enerjisi dönüşüm sistemleri, diğer enerji kaynaklarına dayanan sistemlerden farklıdır, çünkü enerji kaynağı değişen meteorolojik koşullara tabidir. Güneş enerjisi sistemi tasarlamak için ilgilenilen her alanda güvenilir güneşlenme verileri gereklidir (Şekil 2.) (Bird ve Hulstrom, 1980).

Programda güneşlenme özellikleri için mevcut modeller,

- Weather file data (Hava durumu verileri)

- Meinel model (Meinel modeli)

- Hottel model (Hottel modeli)

- Constant value (Sabit DNI değeri)

- $\quad$ Allen model (Allen modeli)

- Moon model (Moon modeli)

hesaplama için mevcuttur.

\subsection{Hava Durumu Verileri (Weather file data)}

Şekil 1.'de seçimi gerçekleştirilmiş alanın yıllık güneşlenme zamanına göre hesaplama işlemleri gerçekleştirilmektedir. 


\subsubsection{Meinel modeli (Meinel Model)}

Meinel modeli; zenit açısını ve dünya dışı güneş ışınımını içerir (Bird ve Hulstrom, 1980).

$$
\delta=\delta_{0}\left[(1-0,14 \alpha) \mathrm{e}^{-0.357(\sec \theta s)^{0,678}}+0,14 \alpha\right.
$$

Burada; $\delta$, radyasyon yoğunluğu, $\alpha$, mesafe $(\mathrm{km}), \theta_{\mathrm{s}}$, Güneş zenit açısıdır.

\subsection{Hottel modeli (Hottel Model)}

Hottel modeli; güneş yoğunluğunu dünya dışı radyasyon, alan yüksekliği ve güneş zirve açısının bir fonksiyonu olarak hesaplamaktadır (NREL, 2018).

$$
\delta=\delta_{0}\left(\mathrm{~d}+\mathrm{b} e^{-c \sec \theta \mathrm{s}}\right)
$$

Burada;

$\mathrm{b}=0,5055+0,00595(6,5-\alpha)^{2}$

$c=0,2711+0,01858(2,5-\alpha)^{2}$

$\mathrm{d}=0,4237-0,00821(6,0-\alpha)^{2}$

değerlerini almaktadır.

\subsection{Sabit DNI Değeri (Constant Value)}

İsminden de anlaşılacağı üzere sabit değer modeli; hesaplamalar sırasında sabit doğrudan normal ışınım (Direct Normal Irradiation (DNI)) değeri belirterek hesaplama gerçekleştirmektedir.

\subsection{Allen Modeli (Allen Model)}

Allen modeli; güneşlenmeyi dünya dışı radyasyon, hava kütle düzeltme faktörü, yoğuşan su ve atmosferik basıncın bir fonksiyonu olarak hesaplamaktadır (NREL, 2018).

$$
\delta=\delta_{0}\left[1-\frac{0,263(K+2,72)}{K+5}(m p)^{\gamma}\right]
$$

Burada;

$\gamma=\frac{0,367(K+11,53)}{K+7,88}$

$m=\frac{1}{\cos \theta s}\left(\theta_{\mathrm{s}}<60^{\circ}\right)$ veya $m=\frac{1}{\cos \theta \mathrm{s}}-41,972213(90-\theta \mathrm{s})^{\beta}\left(\theta \mathrm{s} \geq 60^{0}\right)$,

$\beta=-2,0936381-0,04117341\left(90-\theta_{s}\right)+0,000849854\left(90-\theta_{s}\right)^{2}$

değerlerini almaktadır. $m$, açısal düzeltme faktörü, $K$, yoğuşan su ve $p$, atmosferik basıncı ifade etmektedir.

\subsubsection{Moon Modeli (Moon Model)}

Moon modeli, Allen modelinin alternatif bir regresyon formu olarak kullanılmaktadır (NREL, 2018).

$$
\delta=\delta_{0}\left(0,183 e^{-\frac{m p}{0,48}}+0,715 e^{-\frac{m p}{4,15}}+0,102\right)
$$

Burada; $m$, açısal düzeltme faktörü, $K$, yoğuşan su ve $p$, atmosferik basıncı ifade etmektedir.

Meinel ve Hottel modelleri, sisteme uygulama arazisi için yüklediğimiz veriler sayesinde otomatik olarak hesaplanmaktadır. Sabit değer modeli, DNI verilerini kullanıcı tarafından girilerek hesaplama sistem tarafından gerçekleştirilmektedir. Allen ve Moon modellerinde, ortam basıncı ve uygulama alanının atmosfer verileriyle işlem 
gerçekleștirmektedir. Bu hususlardan dolayı Meinel veya Hottel modelleri uygulama için hesaplama açısından daha net verilerin oluşmasını sağlamakta olup, bu çalışmada sistem modellemesinde, "Meinel" modeli tercih edilmiştir.

\subsubsection{Atmosferik Zayıflama Modelleri (Atmospheric Attenuation Model)}

Heliostat aynalar tarafından yansıtılan güneş ışınları, bir güneş kulesi tesisinin alıcısına giderken atmosferik zayıflama nedeniyle azalır. Atmosferik Zayıflama, ışınımının emilmesi ve saçılması sonucunda dünya atmosferindeki elektromanyetik radyasyonun yoğunluğundaki azalma olarak tanımlanmaktadır. Zayıflama büyüklüğüne dair bilgi eksikliği, verim analizi ve kule tesisi tasarımındaki belirsizlikleri arttırmaktadır. Zayıflama, ayrı bir heliostat ile alıcının odak düzlemi arasındaki düz çizgi mesafesinin bir fonksiyonu olarak kısmi bir kayıp olarak ifade edilmektedir (NREL, 2018; Hanrieder vd., 2016) (Freedictionary, 2020).

Programda atmosferik zayıflama için mevcut modeller,

- DELSOL3 clear day (açık gökyüzü)

- DELSOL3 hazy day (bulutlu/kapalı gökyüzü)

- User-defined (kullanıcı tarafından veri girişi)

hesaplama için mevcuttur.

Mevcut model hesaplamaları için DELSOL tasarım veri tabanı modülünü kullanmaktadır. DELSOL, optik ve ekonomik analizleri içeren bir performans ve tasarım modülüdür. Modül, atmosferik zayıflama, ayna ve alıcı yansıtıcılığı, alıcı radyasyonu, konveksiyon ve boru kayıpları ile birlikte güneşlenme, kosinüs için kısalma, gölgeleme, bloke etme ve dökülmedeki farklılıkları hesaba katmaktadır (SAND, 2008).

DELSOL3 açık ve bulutlu gökyüzü zamanları için hesaplama ve uygulama imkânı sağlayan programda, uygulama günleri için seçim gerçekleştirilmesi gerekmektedir. Sistemde DELSOL modülünün yanı sıra, uygulama alanı için elimizde bulunan verilere göre sisteme veri girişi yapma imkânı sağlamaktadır. Sistem hesaplamasında açık gökyüzü zamanları kullanılarak hesaplama yapılmıştır. SolarPILOT sistemine veri girişi gerçekleştirildiğinde Şekil 3.'deki sistem tarafından otomatik olarak veri kayıpları hesaplanmıştır.

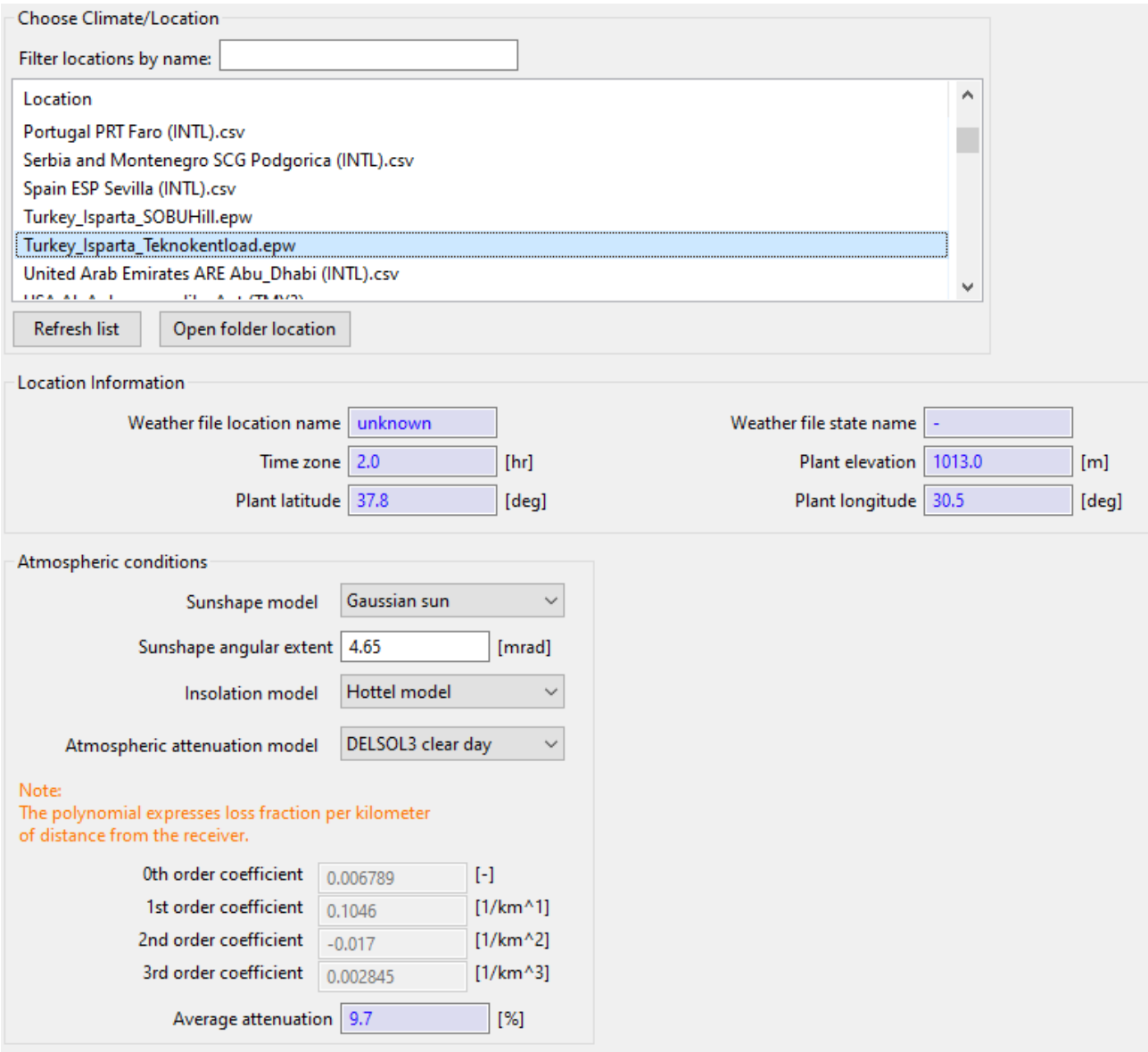

Şekil 3. Uygulama Arazisinin Hava Şartları (Weather Conditions of the Application Area) 


\subsection{Sistem Tasarım Parametreleri (Layout Setup)}

Tasarım noktası, programda uygulama alanına optimum şekilde yerleştirilmesi planlanan heliostatları ve heliostatların performansını değerlendirmek için kullandığı simülasyonları yapılandırmak için veri girişi sağlamaktadır. Performans simülasyonları, bir dizi şema kullanılarak yapılandırılabilir. Ayrıca heliostat performans sıralaması için tercih edilen yöntemin konfigürasyonuna izin verilmektedir (Șekil 4.) (NREL, 2018).

\subsubsection{Tasarım Noktası Tanımı (Design Point Definition)}

Tasarım Noktası, uygulama alanda kullanılması planlanan heliostatların hesaplama kriterlerini, seçimler sonucunda simülasyonu optimize olarak değerlendirmek için veri girişi sağlamaktadır (Șekil 4.).

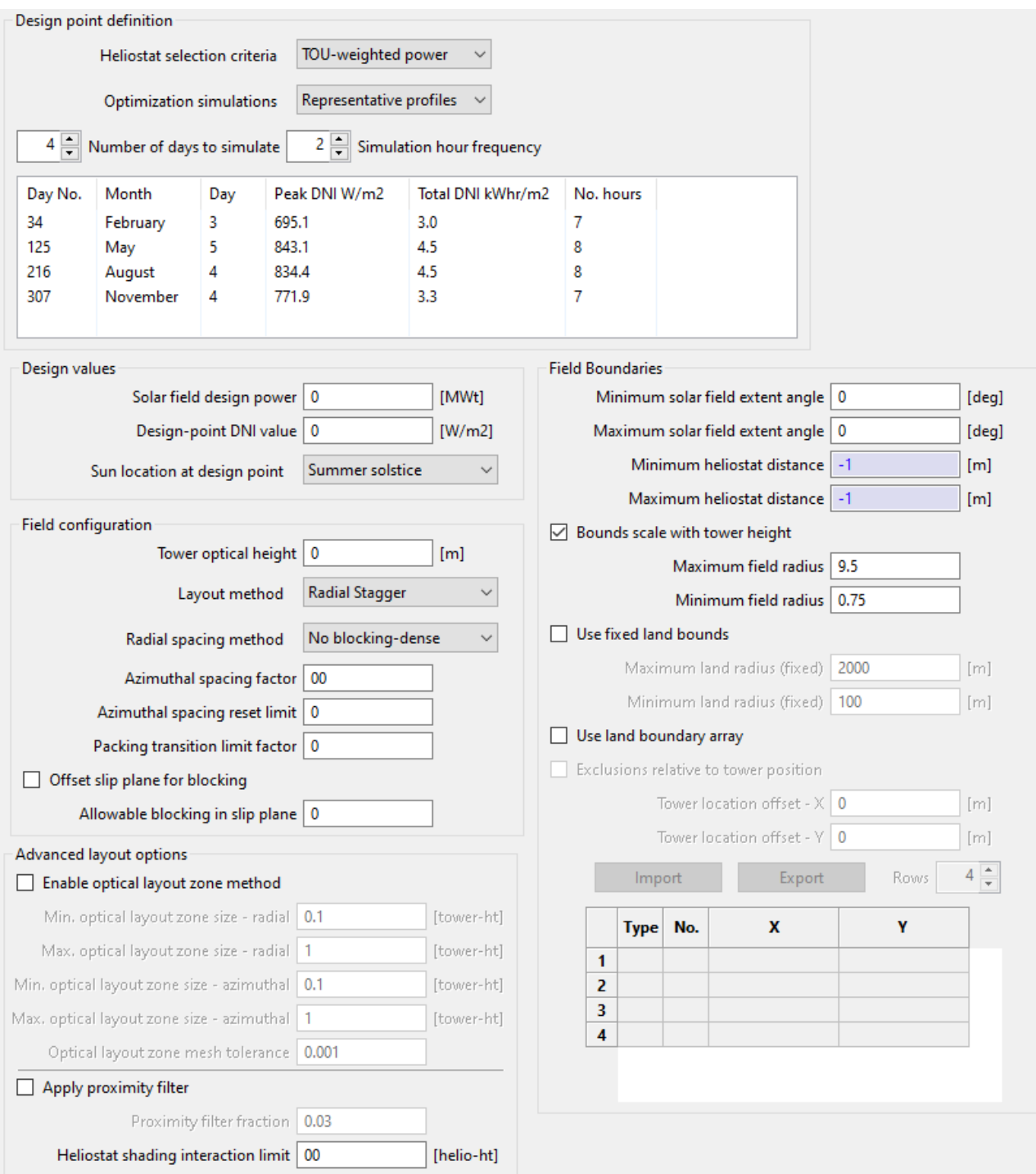

Şekil 4. Sistem Tasarım Parametreleri (Layout Setup)

\subsubsection{Heliostat Seçim Kriterleri (Heliostat Selection Criteria)}

Heliostatların tasarımı için uygulamada çeşitli seçenekler mevcuttur, ancak düzenli kullanım için Alıcı Gücü veya TOU(Time of use) Ağırlıklı Güç modelleriyle hesaplanması, sistem tasarım verimini daha net hesaplama imkanı sunmaktadır. Her bir heliostatın performansı, son mizanpajdaki tercihi sıralamak için aşağıdaki kriterlerden herhangi birinin kullanılabileceği şekilde tasarım noktası simülasyonu gerçekleştirme imkânı sunmaktadır (Șekil 4.) (NREL, 2018).

Programda heliostat seçim kriterleri için mevcut hesaplamalar,

- Power to receiver (Alıcı Gücü)

- Total efficiency (Genel Verimlilik)

- Cosine efficiency (Kosinüs Verimliliği) 
- Attenuation efficiency (Atmosferik Kayıp Verimliliği)

- Intercept efficiency (Önleme Verimliliği)

- Blocking efficiency (Engelleme Verimliliği)

- Shadowing efficiency (Gölgeleme Verimliliği)

- TOU-weighted power (Kullanım Süresine Göre Üretim Gücü)

göre hesaplama imkânı mevcuttur.

Alıcı gücüne göre hesaplamada; heliostat aynalar tarafından yansıtılan güneș ışınlarının, alıcıya odaklandığında oluşturduğu termal güce göre hesaplama gerçekleştirmesidir. Genel verimliliğe göre hesaplamada; uygulama sisteminde kayıpların sistem hesaplamasında düşülmesi sonucunda oluşan verimliliğe göre gerçekleştirilmesidir. Kosinüs Verimliliğine göre hesaplamada; heliostat alana gelen güneş ışını ile heliostatın yüzeyinde normal olan ve kosinüs etkisi olarak adlandırılan bir vektör arasındaki açıdan verimliliği hesaplanarak gerçekleștirilmesidir (Bouamra ve Merzouk, 2019). Atmosferik Kayıp Verimliliğine göre hesaplamada; Güneş ışınlarının yeryüzüne ulaşırken atmosferik yaşanılan kayıplar sonucunda oluşan verimliliğe göre hesaplanarak gerçekleştirilmesidir. Önleme verimliliğine göre hesaplamada, alıcıya gelen güneş ışınının, aynı yerde sonsuz büyüklükteki bir düzleme çarpacak güneş ışınımı varsayımıyla karşılaştırarak işlem gerçekleștirilmesidir (NREL, 2018). Bu alanda yaşanılan yahut ileri zamanlarda yaşanılabilecek kayıplar sonucunda oluşması tahmin edilen verimliliğe göre hesaplama gerçekleştirilmektedir. Engelleme Verimliliğine göre hesaplamada, uygulama alanına yerleştirilen heliostatın diğer heliostattan yansıtılan güneş ışınını engellemesi sonucu yaşanılan kayıplar sonucunda oluşan verimliliğe göre işlem gerçekleştirilmesidir. Gölgeleme Verimliliğine göre hesaplamada, uygulama alanına yerleştirilen heliostatın diğer heliostatı gölgesiyle engellemesi sonucu yaşanılan kayıplar sonucunda oluşan verimliliğe göre işlem gerçekleştirilmesidir. Kullanım Süresine Göre Üretim Gücü hesaplamasında, bir nevi ekonomi modeli olarak düşünülebilecek bu model, ay, gün ve saat olarak sistemin uygulama sürecinde ürettiği elektriğin ücretlendirme tahsis faktörleri tarafından hesaplanması üzerine hesaplama gerçekleștirmektedir (NREL, 2018).

Yapılan uygulama yıl boyunca aktif olarak kullanımı gerçekleștirileceğinden ve uygulama alanı açısından arazi ile ilgili yerleşim probleminin olmamasından kaynaklı, heliostatların birbirlerini gölgeme yahut engelleme gibi bir durumu söz konusu olmamasından ötürü, alıcı gücünden hesaplama gerçekleştirilmesi yukarıdaki kriterlere göre bu sistem için en uygunudur. Bu çalışmada kullanılan sistemin "Power to Receiver (Alıcl Gücü)" modeli üzerinden hesaplaması gerçekleștirilecektir.

\subsubsection{Optimizasyon Simülasyonları (Optimization Simulations)}

Uygulama alanının yerleşimi için heliostat konumları çok önemlidir. Optimizasyon simülasyonları, uygulamada kullanılması planlanan heliostat özelliklerine göre heliostat alan düzenini bu çalışma için modellemektedir (Şekil 4.).

Programda optimizasyon simülasyonları için mevcut hesaplama modelleri,

- Subset of days/hours (Belirlenen Gün ve Saat Simülasyonu)

- Single Simulation Point (Tek Uygulama Noktası)

- Do not filter heliostats (Koşulsuz Heliostat Düzeni)

- Annual Simulation (Ylllık Simülasyon)

- Limited Annual Simulation (Sinırlı Yıllık Simülasyon)

- Representative profiles (Temsili Zamanla Simülasyon)

- Efficiency map + annual (Ylllk Verimlilik Verileri)

göre hesaplama imkanı mevcuttur.

Belirlenen Gün ve Saat Simülasyonu modeli, programın mevcut sürümünde aktifleștirilmemiştir. Tek Uygulama Noktası modeli, tek bir uygulama noktası için verilerin sisteme girilerek hesaplanması gerçekleştirilmektedir. Bu modellemeyi kullanabilmek için uygulamanın gerçekleştirileceği alanın hesaplanması istenilen tarihteki rüzgâr, basınç, DNI ve kuru termometre sıcaklıklarının bilinmesi gerekmektedir. Koşulsuz Heliostat Düzen modeli, uygulanabilir arazi bölgesindeki tüm heliostat konumlarından oluşmakta olup, bu model için veri girişine gerek bulunmamaktadır (NREL, 2018). Ylllık Simülasyon modeli, yllın her günü için simüle gerçekleştirilmekte olup, saatlik olarak hesaplama yapılmaktadır. Sınırlı Yıllık Simülasyon modeli, program tarafından düzenli aralıkla seçilen günler üzerinden simüle gerçekleștirilir. Bu hususta, hesaplama için istenilen gün sayısı girildiğinde, model otomatik olarak günleri kendi ayarlamaktadır. Günler için verileri, sisteme yüklenilen dosyadan almaktadır. Temsili Zamanla Simülasyon modeli, uygulama için belirlenen gün veya günlerdeki ortalama hava durumu verilerine dayanarak, yıl boyunca sınırlı sayıda gün için ortalama günlük profiller oluşturmaktadır. Bu seçenek sınırlı yıllık simülasyon seçeneğiyle aynı şekilde yapılandırılmış olmasına rağmen, seçilen veri noktaları yerine ortalama veriler kullanır (NREL, 2018). Ylllık Verimlilik Verileri modeli, sistem için yıllık verimlilik verileri 
oluşturarak hesaplama gerçekleştirmektedir. Modelin hesaplaması için kaç gün üzerinden simüle etmesi isteniyorsa belirtilir. Belirtilen gün sayısı üzerinden model kendisi uygulama günü belirleyerek hesaplama gerçekleştirir (Şekil 4.).

Heliostatların uygulama alanına yerleștirilmesinde herhangi bir filtreleme ișlemi gerçekleștirmeden hesaplamaların yapılması için, bu çalışma için “Representative Profiles (Temsili Zamanla Simülasyonu)” modeli seçilerek işlemler gerçekleştirilmiştir. Seçilen modelde her ay için sistem tarafından farklı gün seçimi ve seçilen gün için saatlik verileri sistem tarafından otomatik olarak hesaplanmış ve uygulamada kullanılacak veriler Şekil 5. de sunulmuştur.

\begin{tabular}{l|l|l|l|l|l} 
Day No. & Month & Day & Peak DNI W/m2 & Total DNI kWhr/m2 & No. hours \\
4 & January & 4 & 349.4 & 2.4 & 11 \\
34 & February & 3 & 448.2 & 3.4 & 12 \\
64 & March & 5 & 609.0 & 5.0 & 13 \\
95 & April & 5 & 462.1 & 3.6 & 14 \\
125 & May & 5 & 487.8 & 4.1 & 15 \\
156 & June & 5 & 545.5 & 5.2 & 16 \\
186 & July & 5 & 819.8 & 8.2 & 16 \\
217 & August & 5 & 792.3 & 7.5 & 15 \\
246 & September & 4 & 835.8 & 7.4 & 14 \\
277 & October & 4 & 603.4 & 4.6 & 13 \\
307 & November & 4 & 620.3 & 4.7 & 12 \\
338 & December & 4 & 514.8 & 3.5 & 11
\end{tabular}

Şekil 5. Representative Profiles Verileri (Representative Profiles Data)

Burada; Day No.; simülasyon için kullanılan yılın günü, month; simülasyon gününü içeren ay, day; simülasyon günü, Peak DNI; simülasyon gününde hava dosyasında gözlemlenen maksimum DNI, Total DNI; simülasyon gününde $1 \mathrm{~m}^{2}$ deki toplam DNI, No. Hours; simülasyon günündeki hesaplama yapılacak saatlerin periyod sayısını ifade etmektedir.

\subsubsection{Uygulama Tasarım Değerleri (Design Values)}

\subsubsection{Güneş Alan Tasarım Gücü (Solar Field Design Power)}

Alıcı tarafından sistemde kullanılması için istenilen güçtür. Tesis hesaplamasını günlük 10 MWt gücünde olacak şekilde heliostat alan tasarımı planlanmıştır (Şekil 4.).

\subsubsection{Tasarım Noktası DNI Değeri (Design-Point DNI Value)}

Uygulama alanında alıcının bulunduğu noktanın DNI verisidir. Uygulama gerçekleştirilecek alan verileri Tablo 1.'de verilmiş olup, ylllık ortalama DNI verisi üzerinden işlem gerçekleştirilecektir. Bu değer 4,4275 kWh/m²-yl' dır. Uygulama hesabında 4,43 kWh/m²-yll değeri kullanılacaktır.

Tablo 1. Uygulama bölgesi DNI verileri (Application Area DNI Data) (EIGM, 2020)

\begin{tabular}{|c|c|c|c|c|c|c|c|c|c|c|c|c|}
\hline AY & Ocak & Şubat & Mart & Nisan & Mayıs & Haziran & Temmuz & Ağustos & Eylül & Ekim & Kasım & Aralık \\
\hline $\begin{array}{c}\text { DNI(kWh/m } \\
\text { gün })\end{array}$ & 2,06 & 2,53 & 4,21 & 5,3 & 6,29 & 6,8 & 6,75 & 6,07 & 5,09 & 3,8 & 2,41 & 1,82 \\
\hline
\end{tabular}

Uygulama alanı hesaplamasında kullanılması uygun görülen yıllık DNI verisi ve uygulama bölgesinin aylık DNI verileri Tablo 2.'de belirtilmiștir. 
Tablo 2. Isparta, SDÜ-Teknokent Yolu için Yıllık Ortalama DNI ve Aylık DNI Verileri (Isparta, SDÜ-Teknokent Road, Annual Average and Monthly DNI Data)

\begin{tabular}{|c|c|c|c|c|c|c|c|c|c|c|c|c|}
\hline AY & Ocak & Şubat & Mart & Nisan & Mayıs & Haziran & Temmuz & Ağustos & Eylül & Ekim & Kasım & Aralık \\
\hline $\begin{array}{c}\text { DNI(kWh/m²- } \\
\text { yll) }\end{array}$ & 4,43 & 4,43 & 4,43 & 4,43 & 4,43 & 4,43 & 4,43 & 4,43 & 4,43 & 4,43 & 4,43 & 4,43 \\
\hline $\begin{array}{c}\text { DNI(kWh/m²- } \\
\text { gün }\end{array}$ & 2,06 & 2,53 & 4,21 & 5,3 & 6,29 & 6,8 & 6,75 & 6,07 & 5,09 & 3,8 & 2,41 & 1,82 \\
\hline
\end{tabular}

\subsubsection{Uygulama Alanı için Güneş Konumu (Sun Location at Design Point)}

Uygulama hesaplaması için önemli noktalardan birisi de uygulama alanı için güneş konumudur (Şekil 4.).

Programda güneş konumu için mevcut hesaplamalar,

- Summer solstice (Yaz Gündönümü)

- Equinox (Ekinoks)

- Winter solstice (Kış Gündönümü)

- Zenith (Zenit)

- $\quad$ Other (Ek Veri Girişleri)

göre hesaplama imkanı mevcuttur.

Programa uygulama alanı verileri yüklenildiğinde güneş konumu için mevcut hesaplama verileri otomatik olarak sisteme yüklenmektedir. Güneş konumu seçimi gerçekleştirildikten sonra, sistem otomatik olarak hesaplama işlemlerini gerçekleştirmektedir. Yaz Gündönümü, güneşin dünyaya yaz gündönümü konumuyla işlem gerçekleştirilmektedir. Yaz gündönümü, güneș ıșınlarının Yengeç Dönencesi’ne yılda bir kez (21 Haziran olarak kabul edilir) dik geldiği an olarak tanımlanmaktadır (Wikipedia Yaz Gündönümü, 2020). Ekinoks, dünya genelinde gece ve gündüz sürelerinin eşit olduğu gün olarak bilinir. Ekinoks, aydınlanma çemberinin kutuplardan geçtiği anda gerçekleşen bir olaydır. Güneş bu anda Kuzey Yarımküreyi ve Güney Yarımküreyi eşit miktarda aydınlatmaktadır. (Sarıgül, T., 2018; Wikipedia Ekinoks, 2020). Kış Gündönümü, güneş ıșınlarının Oğlak Dönencesi'ne yılda bir kez (21 Aralık olarak kabul edilir), dik geldiği an olarak tanımlanmaktadır (Wikipedia Kış Gündönümü 2020). Zenit, yatay yüzey $(\beta=0)$ için güneş geliş açısıdır. Doğrudan güneş ışınımı ile yatay düzlemin arasındaki açıdır (Ceylan ve Gürel, 2017). Uygulamada, doğrudan güneş pozisyonu kullanımı gerçekleştirilmektedir ( $90^{0}$ yükseklik, $0^{0}$ azimut) (NREL, 2018). Ek Veri Girişleri, uygulama alanı için güneş konumu kullanıcı tarafından veri girişi yapılarak hesaplama imkânımız bulunmaktadır.

Yaz gündönümü, ekinoks, yaz gündönümü hesabı için kabul edilen 21 Haziran, kış gündönümü hesabı için kabul edilen 21 Aralık, ekinoks için, Kuzey Yarıküre'de yaklaşık olarak 21 Mart İlkbahar Ekinoksu - 23 Eylül Sonbahar Ekinoksu'dur. Güney Yarıüre'de yaklaşık olarak 21 Mart Sonbahar Ekinoksu- 23 Eylül İlkbahar Ekinoksu, tarihlerinde uygulama hesaplarının gerçekleştirilmesi için uygulama imkânı sunmaktadır.

Bu çalışmada, yıllık olarak genel sistem tasarımı gerçekleştirilmesi planlamasından dolayı zenit modeli uygulama için ideal olup, bu çalışmanın sistem hesaplamalarında "Zenit Modeli" uygulama için tercih edilmiştir.

\subsubsection{Field Configuration (Alan Düzenlemesi)}

\subsubsection{Kule Optik Yüksekliği (Tower Optical Height)}

Kule optik yüksekliği, heliostat pivot noktası ile alıcının orta noktası arasındaki mesafeyi belirtmektedir (Şekil 6.). Bu çalışmada kullanılan sistem için bu değer 41 m'dir. 


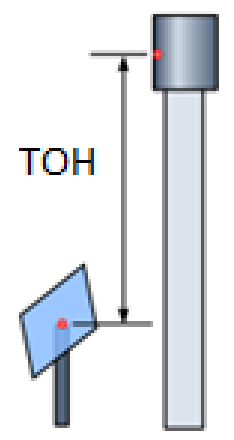

Şekil 6. Kule Optik Yüksekliği (Tower Optical Height) (NREL, 2018)

\subsubsection{Heliostat Düzen Yönetimi (Layout method)}

Genel güneş kulesi sistemlerinde uygulanan heliostat ayna alan uygulamalarının modellendirilmesidir (Șekil 4.). Programda;

- Radial Stagger (Radyal Basamaklama)

- Cornfield (Misir Tarlasi)

- User-defined (Kullanıcı Tarafından Veri Giriși)

modelleri mevcuttur.

\subsection{Radyal Basamaklama (Radial Stagger)}

Heliostat yerleşimi için "radyal basamaklama" yöntemini kullanır. Bu yöntemde heliostat sıraları, sabit yarıçaplarda izo-azimuthal çizgileri boyunca dönüşümlü olarak yerleștirilir (Şekil 7.) (NREL, 2018).

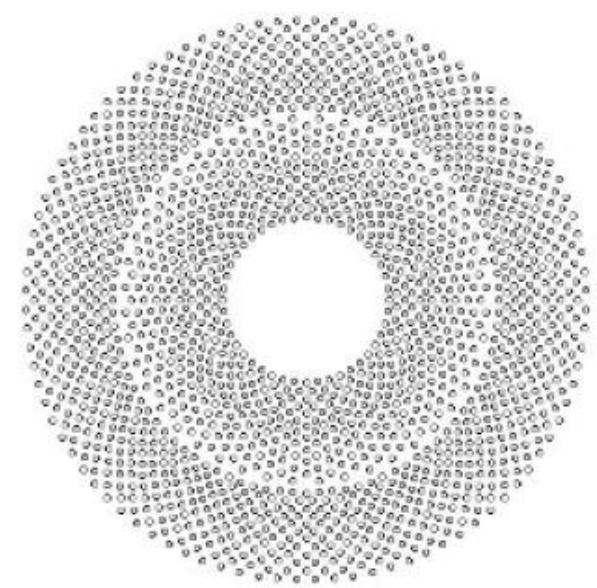

Şekil 7. Radial Stagger Genel Arazi Yerleșimi (Radial Stagger General Land Overlay) (European Commission, 2020)

\subsection{Mısır Tarlası (Cornfield)}

İsminden de anlaşılacağı üzere mısır tarlaları gibi aralarında belirli mesafe bırakılarak, düz bir sırada yerleştirme düzenidir. $\mathrm{Bu}$ yerleşimle gerçekleștirilen heliostat uygulamalarında üst görünümü dikdörtgen şeklini anımsatmaktadır (Şekil 8). 


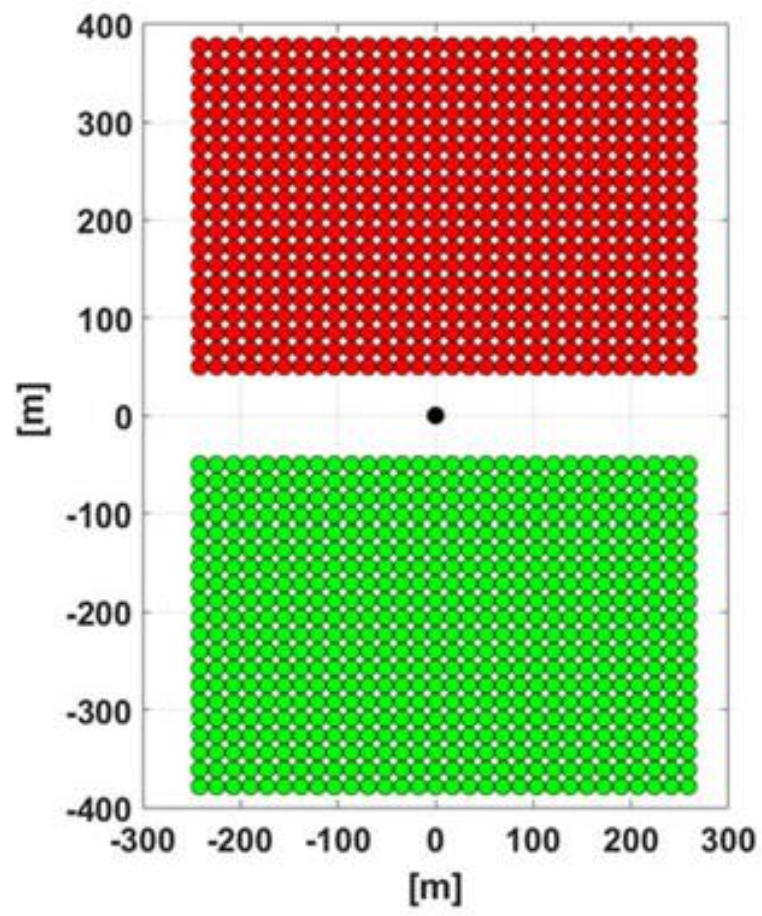

Şekil 8. Cornfield Genel Arazi Yerleşimi (Cornfield General Land Overlay) (Gadalla ve Saghafifar, 2018)

\subsection{Kullanıcı Tarafından Veri Girişi (User-Defined)}

Uygulama alanı için heliostat pozisyonlarını kullanıcı tarafından girilerek hesaplama imkânı bulunmaktadır (Şekil 4.).

Literatürde yapılan araștırmalara göre (bkz. (Arrif vd., 2018)), radial staggers düzeninin, cornfield düzeninden daha verimli olduğu tespit edilmiștir. Bu husustan dolayı "Radial Stagger (Radyal Basamaklama)" yönetimi kullanımı uygulama için idealdir. Uygulama için seçilen modelde aşağıda belirtilen veri girişleri gerekmektedir. İstenilen veri girișleri;

- Radial spacing method (Radyal Aralık Yöntemi)

- No blocking-dense (Engelleme Olmadan Heliostat Yerleşim)

- Eliminate blocking (Engelsiz Heliostat Yerleşimi)

- DELSOL Empirical Fit (DELSOL Ampirik Uyum)

- Azimuthal Spacing Factor (Azimut Aralı̆̆ Sinırı)

- Azimuthal Spacing reset limit (Azimut Aralığı Sifırlama Sınırı)

- Offset slip plane for blocking (Engelleme için Ofset Kayma Düzlemi)

- Allowable blocking in slip plane (Kayma Düzleminde İzin Verilen Engelleme)

istenilmekte olup, aşağıda sırasıyla açıklanmıştır.

\subsection{Radyal Aralık Yöntemi (Radial Spacing Method)}

Radial Stagger uygulamasını gerçekleştirmek için algoritma hesaplaması için radyal aralık yönetimi (Radial spacing method) belirlenmesi gerekmektedir (Şekil 4.). Programda;

- Eliminate blocking (Engelleme Olmadan Heliostat Yerleşim)

- $\quad$ No blocking-dense (Engelsiz Heliostat Yerleşimi)

- DELSOL Empirical Fit (DELSOL Ampirik Uyum)

modelleri mevcuttur.

Engelleme olmadan heliostat yerleşim modeli, heliostatların birbirlerini gölgeleme, bloklama gibi olayların yaşanmayacağı bir şekilde heliostat yerleşimini gerçekleștirmektedir. Engelsiz heliostat yerleşimi, engelleme olmadan heliostat yerleşimi modelinin bir varyasyonudur. Heliostat sıralarının arasındaki ayrım, izo-azimuthal çizgileri boyunca düşen heliostatların alıcıya görünümü engellememesi için kuleden her sıranın radyal mesafesinin bir fonksiyonu olarak hesaplanmaktadır (NREL, 2018). DELSOL Ampirik Uyum modeli, DELSOL3 
yazılımıyla sistemde kuleden uzaklığın, heliostat yüksekliğinin, heliostat genişliğinin, heliostat geometri tipinin (dikdörtgen, yuvarlak vb.) ve alıcı tipinin (bölmeli, silindirik vb.) çeşit aralığı korelasyonunu içermektedir (NREL, 2018).

Uygulama alanı açısından arazi ile ilgili yerleşim probleminin olmaması, heliostatların gölgeleme vb. birbirlerini engellemelerinden kaynaklı verim düşüşü istenilmediğinden dolayı Engelleme olmadan heliostat yerleşim modeli (Eliminate blocking), uygulama için tercih edilmiştir.

\subsection{Azimut Aralığı Sınırı (Azimuthal Spacing Factor)}

Heliostatların, yapısal genişlikleri açısından aynı sıradaki heliostatlar arasındaki başlangıç aralığıdır. Kayma düzleminden sonra veya alanın ilk sırasındaki bir sıradaki heliostat ayrımı, Azimutal Aralık faktörünün Heliostat genişliği ile çarpılmasıyla belirlenir. Bu değer, her gruptaki ilk halkadaki heliostatlar arasındaki azimuthal aralığı, heliostat genişliğinin “iki (2) katına" eşittir (Siala ve Elayeb, 2001).

\subsection{Azimut Aralığı Sıfırlama Sınırı (Azimuthal Spacing Reset Limit)}

Bir kayma düzleminin uygulandığı ve sonraki radyal sıranın başlangıç azimut boşluğuna geri döndüğü aralık oranı sınırını ifade etmektedir. Azimutal aralık oranı, bir sıradaki heliostatlar arasındaki azimutal aralığın minimum (başlangıç) aralığa bölünmesiyle belirlenir. Herhangi bir satırdaki boşluğun ilk boşluğa oranı, boşluğun ilk değere nereye döneceğini belirler. Bu değer, (Mehos vd., 2017) sistem hesaplamalarında 1,21, (Wagner ve Wendelin, 2018) sistem hesaplamalarında 1,31, şu an uygulama sisteminde 1,33 olarak alınmaktadır. Güncel olarak uygulama alanının hesaplama detayları arttığında değerin arttığı gözlemlenmiş olup, bu çalışmada "1,33" değeri kullanılması uygundur.

\subsection{Engelleme için Ofset Kayma Düzlemi (Offset Slip Plane for Blocking)}

Etkinleștirilmesi durumunda, kayma düzleminden sonraki ilk satır (yani, azimuthal aralığının başlangıç değerine sıfırlandığı ilk satır), kayma düzleminden önceki son satır ile ilk satır arasında engelleme ortadan kaldırılacak şekilde radyal olarak aralıklandırma işlemi için kullanılmaktadır.

\subsection{Kayma Düzleminde İzin Verilen Engelleme (Allowable Blocking in Slip Plane)}

Kesirli bloklama, kayma düzleminden önceki iç sıra ile kayma düzleminden sonraki dış sıra arasında en olumsuz yerleștirme durumuna göre hesaplama gerçekleştirmektedir. 0 değeri, kayma sırası aralığının tüm olası engellemeyi ortadan kaldırmak için yeterli olacağını belirtirken, 1 değeri, alandaki konuma bağlı olarak bazı heliostatların tamamen bloke olabileceğini gösterir. Satırlar arasındaki boşluk, belirtilen değere bakılmaksızın çarpışmayı önlemek için yeterli olmalıdır (NREL, 2018).

Arazi alanı olarak bir problemin olmaması hem de yukarıda belirtilen hususlardan ötürü heliostat düzleminde verimliliğin azalmaması için "sıfır (0)" değerini alması idealdir.

\subsubsection{Gelişmiş Düzen Seçenekleri (Advanced Layout Options)}

\subsubsection{Optik Yerleşim Bölgesi Yöntemi (Enable Optical Layout Zone Method)}

Optik yerleşim bölgesi yöntemi, heliostatları birbirine yakınlık ve bir tolerans bandı içindeki tahmini kesme faktörüne göre bölgelere gruplandırır. Bölgenin boyutu ve konumu, kesme faktörünün yerel tahminine bağlı olup, mekânsal olarak değişiklik göstermektedir. Tek bir bölge içindeki heliostatlar, yerleşim simülasyonları sırasında, her bölge için kesişme faktörünün, bölgenin sentroidi kullanılarak sadece bir kez hesaplanacağı şekilde birlikte düşünülür. Bu bölgedeki heliostatlar, bölge genelindeki kesişim değerini referans alır, ancak her bir heliostat için diğer tüm optik terimler hesaplanır. Bu yöntem hesaplama maliyetini azaltır, ancak nihai düzeni değiștirebilir ve dikkatli kullanılmalıdır (NREL, 2018).

Bu hususla alakalı daha önceki adımlarda alan modeli seçimi gerçekleştirilmiştir. Bu husustan dolayı, bu çalışmada uygulanmamıştır.

\subsubsection{Heliostat Gölgeleme Etkileşim Sınırı (Heliostat Shading Interaction Limit)}

Heliostat bloke etme ve gölgeleme, gelen ışınlama yönü boyunca heliostat köşe noktalarından vektörler yansıtılarak ve vektörlerin yakındaki bir bölgedeki diğer heliostatlarla kesişip kesişmediğini belirleyerek 
hesaplanmaktadır. Heliostatların test edildiği bölgenin yarıçapı, heliostat yüksekliği ile heliostat gölgeleme etkileşim sınırı çarpılarak hesaplanır. Varsayılan olarak, bu değer 100'e eşittir. Beklendiği gibi, daha düşük güneş açlarında yakınsama için daha büyük bir sınır gereklidir. Çoğu durumda, yakınsama için 50 sınırı yeterlidir (NREL, 2018).

Uygulama planlanan arazi için güneş açlları incelendiğinde (bkz. (European Commission, 2019)) "100" değeri uygulama hesaplamalarında kullanılmıştır.

\subsubsection{Alan Sinırları (Field Boundaries)}

Bu model, heliostatların yerleştirileceği arazi bölgesini belirlemek için çeşitli alternatifler sunmaktadır. Seçenekler arasında, arazi alanının kule yüksekliğinin bir fonksiyonu olduğu ölçekli sınırlar, heliostatların yerleştirilebileceği kule etrafında ortalanmış minimum ve maksimum sabit yarıçapı belirten sabit sınırlar ve dâhil edilen veya hariç tutulan arazi alanlarını temsil edebilecek çokgen şekiller belirtme seçeneği bulunmaktadır. Aynı anda birden çok arazi sınırı yöntemi kullanılabilir. Așağıdaki bölümde, alan sınırlarını özelleștirmek için seçenekler ve girdiler açıklanmaktadır (Şekil 4.) (NREL, 2018).

Minimum Güneş Açısal Alanı (Minimum Solar Field Extent Angle), heliostatların yerleştirilebileceği saat yönünün tersine istikamette açısal değerlerle belirlenmektedir. $-180^{\circ}=+180^{\circ}=$ Güney; $0^{\circ}=$ Kuzey; $+90^{\circ}=$ Doğu; $-90^{0}=$ Batı yönlerini ifade etmektedir (NREL, 2018). Maksimum Güneş Açısal Alanı (Maximum Solar Field Extent Angle), heliostatın yerleştirilebileceği saat yönünde açısal değerlere göre sınırları belirlenmektedir. $-180^{\circ}=+180^{\circ}=$ Güney; $0^{0}=$ Kuzey; $+90^{0}=$ Doğu; $-90^{0}=$ Batı yönlerini ifade etmektedir (NREL, 2018). Bu çalışmada, minimum ve maksimum güneş alan açısı “ $\pm 180^{0}$ ” değerindedir. Minimum Heliostat Mesafesi (Minimum Heliostat Distance), bir heliostatın alıcı konumundan uzağa yerleştirilebileceği gerçek minimum radyal mesafeyi belirtmektedir. Bu değer yalnızca kule yüksekliğine sahip sınır ölçeği ve sabit arazi sınırları seçeneklerini kullanmak için hesaplanmaktadır. Maksimum Heliostat Mesafesi (Maximum Heliostat Distance), bir heliostatın alıcı konumundan uzağa yerleştirilebileceği gerçek maksimum radyal mesafeyi belirtmektedir. Bu değer yalnızca kule yüksekliğine sahip sınır ölçeği ve sabit arazi sınırları seçeneklerini kullanmak için hesaplanır. Minimum ve maksimum heliostat mesafesi değerleri sistem tarafından otomatik olarak hesaplanmaktadır.

\subsubsection{Kule Yüksekliği Sınırları (Bounds Scale with Tower Height)}

Uygulama arazisinin belirli alan sınırlamalarından kaynaklı, arazinin minimum ve maksimum alan sınırlarının kule yüksekliğine ölçeklenip ölçeklenmeyeceğinin hesabını gerçekleștirmektedir.

\subsubsection{Maksimum Alan Yarıçapı (Maximum Field Radius)}

Heliostatların sahaya yerleștirilebileceği eşdeğer kule yükseklikleri bakımından maksimum radyal mesafe değeridir. Gerçek mesafe, kule yüksekliği ile çarpılan bu değere eşittir. Alıcı ile son sıra heliostat arasındaki maksimum mesafe olarak da ifade edilebilir. Bu çalışmadaki sistem için "10" değeri alındığında minimum heliostat mesafesi “ $410 \mathrm{~m}$ ” olmaktadır.

\subsubsection{Minimum Alan Yarıçapı (Minimum Field Radius)}

Heliostatların sahaya yerleștirilebileceği eșdeğer kule yükseklikleri bakımından minimum radyal mesafe değeridir. Gerçek mesafe, kule yüksekliği ile çarpılan bu değere eşittir. Alıcı ile ilk sıra heliostat arasındaki minimum mesafe olarak da ifade edilebilir. Bu çalışmadaki sistem için " 0,5 " değeri alındığında minimum heliostat mesafesi “20,5 m” olmaktadır.

Maksimum ve minimum alan yarıçapları için sistemsel değer belirlemeleri, uygulama aşamasında değerlerin denenerek heliostat verimliliklerin optimum seviyede olmasına dikkat edilerek seçilmiştir. Maksimum alanın artması ve minimum alanın güneş kulesine yakın olması, heliostat ayna yansıtma verimliliğinin düşük olmasına sebebiyet vermesinden ötürü, sistemin genel değerlendirmeleri neticesinde tavsiye ettiği değerler de incelenerek, ortalama olarak belirtilen değerler tespit edilerek kullanılmıştır.

\subsubsection{Sabit Arazi Sınırları (Use Fixed Land Bounds)}

Minimum ve maksimum alan sınırlarının, sabit minimum ve maksimum değerleriyle sınırlanıp sınırlanmayacağının hesabı gerçekleştirilmektedir. Bu çalışmada uygulama arazisi alan sınırlandırması olmadığından dolayı hesaplama yapılmasına ihtiyaç bulunmamaktadır. 


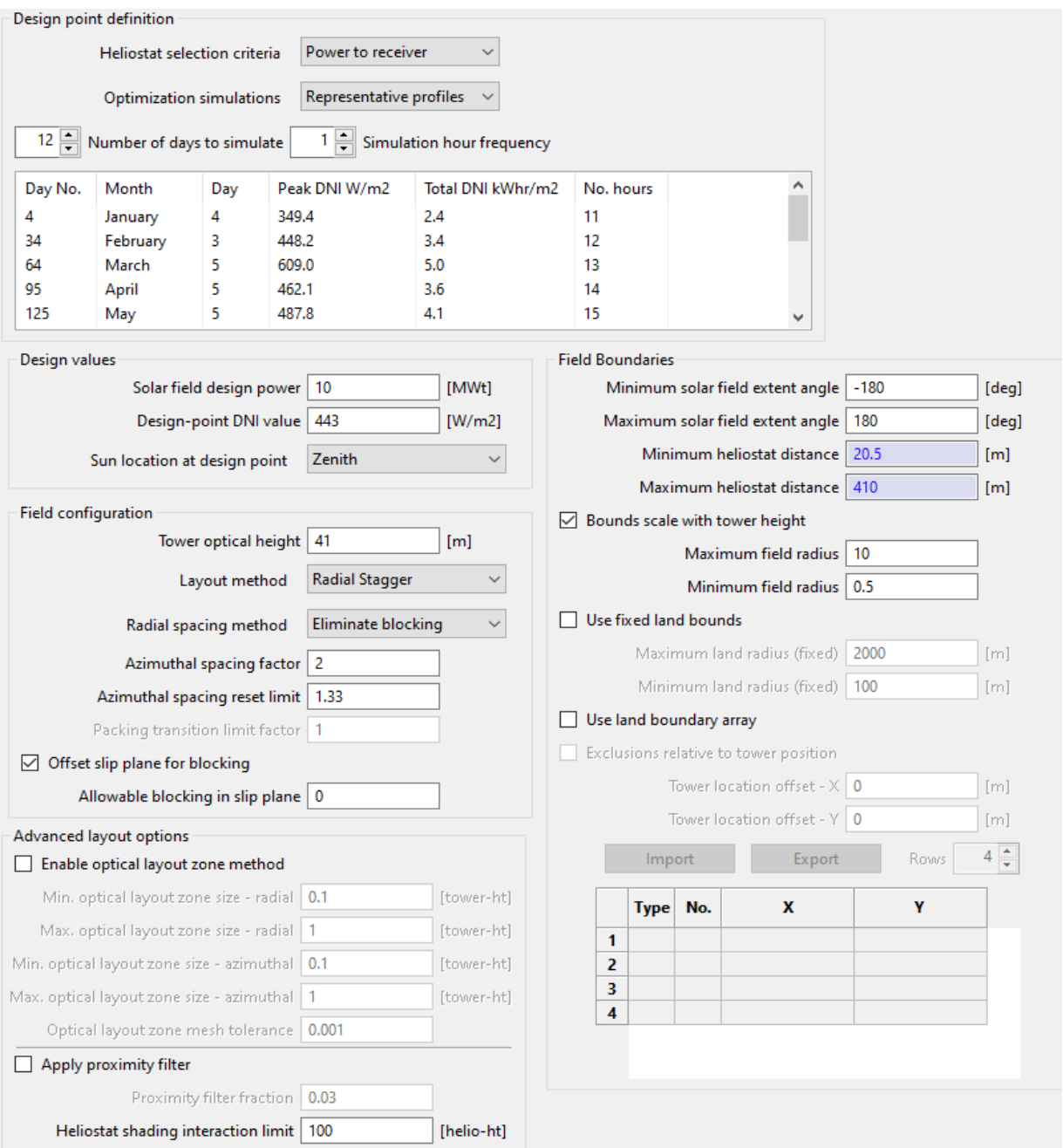

Şekil 9. Isparta, SDÜ-Teknokent Yolu için Uygulama Parametreleri (Application Parameters for Isparta, SDÜ-Teknokent Road)

Uygulama alanı için belirlenen parametreler sisteme girildiğinde Şekil 9.'daki veriler ortaya çıkmaktadır.

\subsection{Heliostatlar (Heliostats)}

\subsubsection{Uygulama için Kullanılacak Heliostat Modeli (Heliostat type use)}

Sistemde, birden fazla heliostat geometrisini aynı uygulama alanında modelleme imkânı bulunmaktadır. Bu hususla alakalı programda;

- Use Single Template (Tek Heliostat Boyutu Kullanımı)

- Specified Range (Farklı Geometrideki Heliostat Aralıkları)

- Even Radial Distrubution (Eşit Radyal Dağılımlı)

modelleri mevcuttur (Șekil 10.).

Tek heliostat boyutu kullanımı modelinde, uygulama alanında tüm heliostatlar aynı geometriye sahiptir. Heliostat ile ilgili hesaplamaların tamamında tek bir heliostat sistemi kullanılmaktadır. Farklı geometrideki heliostat aralıkları modelinde, uygulama alanında farklı geometrik özellikleri olan heliostat aynaların alana yerleşimi hesabı için kullanılmaktadır. Bu hesaplamanın gerçekleștirilebilmesi için geometrik özellikleri farklı heliostat aynaların radyal ve azimutal aralıklarının belirtilmesi gerekmektedir. Eşit radyal dağılımlı modelinde, radyal dağılımda, uygulamada kullanılması için planlanan heliostat aynalar eşit aralıklı radyal alan kaplayacak şekilde atamaktadır.

Tek bir heliostat geometrisi kullanılacağından dolayı “Use Single Template(Tek Heliostat Boyutu Kullanımı)” modeli uygulama için tercih edilmiştir. Uygulama için veri girişi sağlanılacak heliostat Template 1 olarak adlandırılmıştır. Sistemde yaşanılan problemden kaynaklı ismi değiştirilmemiştir. 
Heliostat geometrisi (Heliostat Geometry), heliostat kaidesini belirlemek için parametreler içermektedir. Heliostat eni (Structure Width), heliostat yapısının yatay boyutudur. Bu çalışmada sistem için kullanılan değer “ $6 m^{\prime} d i r^{\prime}$. Heliostat Yüksekliği (Structure Height), heliostat yapısının yükseklik boyutudur. Bu çalışmada sistem için kullanılan değer " $4 m^{\prime}$ 'dir". Heliostat Çarpışmama Yarıçapı (Heliostat Collision Radius), heliostatların birbirleriyle çarpıșmaması için aralarında oluşturulması gereken mesafeyi belirtmektedir. Bu değer otomatik olarak hesaplanmakta olup veri girişi gerçekleştirildiğinde, bu çalışmada sistem için kullanılan değer "3,6 m'dir". Birden Fazla Farklı Boyutlarda Heliostat Ayna Kullanımı (Use Multiple Panels), heliostat'ı kaide kullanarak çoklu modelleme imkânı sunmaktadır. Uygulama için tek bir heliostat boyutu kullanımı gerçekleștirildiğinden dolayı bu modelin kullanılmasına gerek yoktur.

\subsubsection{Odaklama Parametreleri (Focus Parameters)}

Heliostat aynaların alıcıya odaklanması için programda;

- $\quad$ Flat (Eğimsiz)

- At slant (Eğimli)

- Group average (Ortalama Eğimli)

- User-defined (Kullanıcı Veri Girişli)

modelleri kullanılır.

Eğimsiz modelde, heliostatın eğriliği yoktur ve düz, düzlemsel bir yüzey olarak işlem gerçekleştirilir. Eğimli modelde, heliostat odak uzaklığı, heliostat pivot noktası ile alıcı centroid arasındaki mesafeye eşit olarak gerçekleştirilir. Ortalama Eğimli modelde, heliostat odak uzunluğu, geçerli şablonu kullanan tüm heliostatların ortalama eğim aralığına eşit olarak hesaplama işlemi gerçekleştirilir. Kullanıcı Veri Girişli modelde, odak uzunluğunu hem yatay hem de dikey yönlerde belirleyerek hesaplama işlemini gerçekleştirilir.

Bu dört (4) modelden "Flat (Eğimsiz)" modelin kullanılması uygulama için tercih edilmiştir.

2.3.4. Optik Sapma Parametreleri (Optical Error Parameters)

\subsubsection{Açısal Sapmalar (Pointing Errors)}

Yükseklik Açısal Sapması (Elevation Pointing Error), normal bir dağılım varsayıldığında, yükselme tahrikindeki açısal hatanın standart sapması. Bu değer, (Qui vd., 2020) için sistem hesaplamalarında 0.46 mrad olarak tespit edilmiş olup, (Khalsa vd., 2020), deneylerle hata sapmasını teorik olarak $0.1 \mathrm{mrad}$ değerine indirgemiştir. Bu uygulama için “0.46 mrad” değeri kullanılması kabul edilmiştir. Azimut Açısal Sapması (Azimuth Pointing Error), normal dağılım varsayımıyla azimut sürücüsünde açısal hatanın standart sapmasıdır. Bu değer, (Qui vd., 2020) için sistem hesaplamalarında $0.46 \mathrm{mrad}$ olarak tespit edilmiş olup, (Khalsa vd., 2020), deneylerde $0.4 \mathrm{mrad}$ değerine indirgenmiştir. Bu uygulama için “0.46 mrad” değeri kullanılması kabul edilmiștir.

\subsubsection{Yüzey Eğim Sapmaları (Surface Slope Errors)}

X (Yatay) Düzleminde Yüzey Eğim Sapması (Surface Slope Error in X), heliostat yüzeyinin açısal yer değiştirmesinin (yatay) normal bir dağılım varsayarak yatay yönde standart sapmasıdır. Y (Düşey) Düzleminde Yüzey Eğim Sapması (Surface Slope Error in Y), heliostat yüzeyinin açısal yer değiştirmesinin (düşey) normal bir dağılım olduğu düşünüldüğünde dikey yönde standart sapmasıdır.

Yüzey eğim hataları için bu değerler, Andraka için 1.5 mrad'lık bir eğim hatası bildirirken, daha detaylı raporlar incelediğinde 1.5 ila $2.5 \mathrm{mrad}$ arasında bir eğim hatası aralı̆̆ını göstermektedir. (Andraka, 2008.), uygulama için "1.5 mrad" değeri kullanılması kabul edilmiştir.

\subsubsection{Yansıtılan Işın Sapmaları (Reflected Beam Errors)}

X (Yatay) Düzleminde Yansıtılan Işın Sapması (Reflected Beam Error in X), speküler yansımanın normal bir dağılım varsayımıyla yüzeyden yatay yönde standart sapmasıdır. Y (Düşey) Düzleminde Yansıtılan Işın Sapması (Reflected Beam Error in Y), normal dağılım varsa, aynasal yansımanın yüzeyden düşey yönde standart sapmasıdır.

Işın hataları için bu değerler; (Wang vd., 2020), için normal eğim hatasının 2 mrad olduğu, (Leea vd., 2015), için makul ölçüde küçük bir 2 mrad değerinde yüzey eğim hatasının standart sapmasını varsayımı gerçekleștirilmiş ve uygun değer olduğu tespit edilmiştir (Leea vd., 2015). (Göttsche vd., 2017) için sayısal yaklaşımı kullanan eğim hatası sonucu, analitik yöntem kullanıldığında 2.256 mrad ve $2.22 \mathrm{mrad}$ değerlerinin uygunluğu tespit edilmiştir. Uygulamamız için "2.23 mrad” değeri kullanılması kabul edilmiştir. 
Toplam Yansıtma Sapması (Total Reflected Image Error), yansitılan görüntünün, tüm hata kaynakları dâhil olmak üzere heliostattan etkin standart sapmasını gösteren, sistem tarafından otomatik olarak hesaplanmaktadır.

\subsubsection{Heliostat Ayna Performans Parametreleri (Mirror performance parameters)}

Yansıtıcı Yüzey Oranı (Reflective Surface Ratio), aktif yansıtıcı ayna alanının, toplam heliostat ayna alanına oranı olarak hesaplanmaktadır. Yansıtıcı yüzey oranında; (González, 2016), yaptığı araştırmalarda minimum 0,93 olabileceği, (Hekim, 2017), yaptığı araștırmalarda günümüz teknolojileri sayesinde 0,97 verimliliğin sağlandığı tespit edilmiştir. Uygulama için “0,97” verim değeri kullanılması kabul edilmiştir. Heliostat Ayna Yansıtıcılığı (Mirror Reflectivity), aynanın bozulmamış veya temiz durumda taban yüzey yansıtıcılığıdır. Heliostat tarafından verilen güç ayna yansıtma oranı ile orantılıdır. Ayna yansıtma oranında; (Wang vd., 2020), 0,95, (Bonanos, 2012) ise 0,90 yansıtma oranlarının olduğunu tespit etmişlerdir. Uygulama için “ 0,95 ” verim değeri kullanılması kabul edilmiştir. Kirlenme Faktörü (Soiling Factor), yüzey kirliliği hesaba katıldıktan sonra yansıyan ışığın oranıdır. Uygulama için “0,95” verim değeri kullanımı tercih edilmiştir.

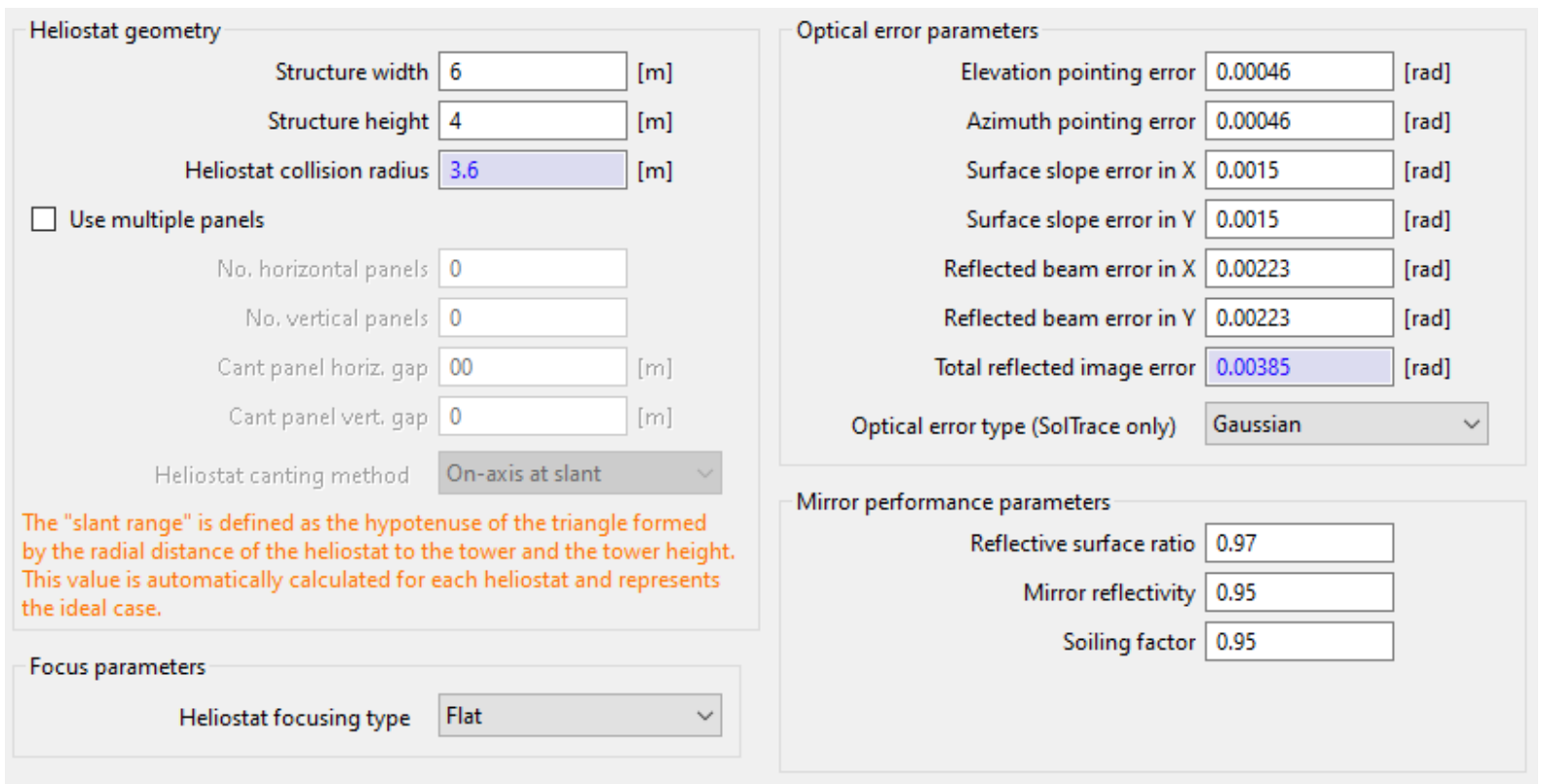

Şekil 10. Isparta, SDÜ-Teknokent Yolu için Heliostat uygulama parametreleri (Heliostat application parameters for Isparta, SDÜ-Teknokent Road)

Heliostat için belirlenen uygulama parametreleri sisteme girildiğinde Şekil 10.'deki veriler ortaya çıkmaktadır.

\subsection{Alıcı (Receiver)}

\subsection{1. Çoklu Alıcı Hedef Noktası ve Düzen Optimizasyonu (Multi-Receiver Aimpoint and Layout Optimization)}

SolarPILOT, aynı heliostat alandan güç alan çoklu alıcıların simülasyon uygulamasına izin vermektedir. Yazılım, alıcı seçiminin bir işlevi olarak heliostat performansını, her bir alıcı için toplam güç gereksinimlerini ve güneş konumunun bir fonksiyonu olarak performanstaki değişikliği hesaba katarken, her bir alıcıya heliostat atamak için en iyi stratejiyi belirlemektedir. SolarPILOT, her bir alıcı için yeterli performansı sağlamak üzere düzen sırasında hem heliostat seçimini optimize etmek hem de alıcı güç kısıtlamalarını gerçekleştirirken, alan güç çıkışını en üst düzeye çıkarmak için performans çalışmaları sırasında belirli bir heliostat alanının optimum atamasını sağlamak için geliştirilmiştir (NREL, 2018). 


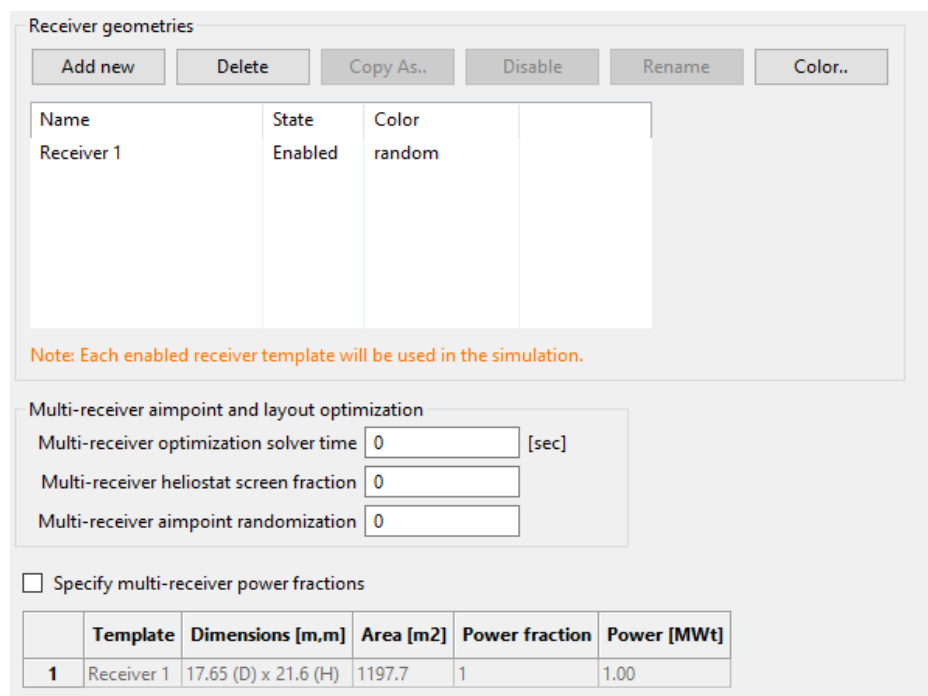

Şekil 11. Isparta, SDÜ-Teknokent Yolu Çoklu Alıcı Verileri (Isparta, SDÜ-Teknokent Road Multiple Receiver Data)

Bu uygulamada tek bir alıcı kullanılacak olup, bundan dolayı Şekil 11.'de veri girişi istenilen Multi-Receiver Aimpoint and Layout Optimization ve specify multi-receiver power fractions seçimi gerçekleştirilmeyecektir.

\subsubsection{Alıcı Geometrisi (Receiver Geometry)}

Alıcı Tipi (Receiver Type) için, alıcının sistemsel uygulaması için programda (Şekil 12.);

- Düz Plaka (Flat Plate)

- Silindirik (External Cylindrical)

modelleri kullanılmaktadır.

Düz Plaka (Flat Plate) modelinde alıcı, düz bir plaka olarak kullanılmıştır. Isı emici yüzey, aksi belirtilmedikçe, kuzeyde ufka doğru bakan bir yüzey normal vektörü olan düz bir düzlem içinde yer almaktadır. Silindirik (External Cylindrical) modelinde alıcı, silindirik modellemedir. Isı emici yüzey, belirtilen çap ve yükseklikte bir silindir olarak tanımlanır. Alıcının merkez ekseni yukarıya doğrudur.

Uygulama için “External Cylindrical (Silindirik Alıcı)" modeli uygulama için tercih edilmiştir.

Alıcı Yüksekliği (Receiver Height), silindir olarak uygulaması planlanan alıcının yüksekliğidir. Bu uygulama için alıcı yüksekliği "10m" olarak alınmıştır. Alıcı Çapı (Receiver Diameter), silindir olarak uygulaması planlanan alıcının çapıdır. Bu uygulama için alıcı çapı " $5 \mathrm{~m}$ " olarak alınmıştır. Alıcı Kabul Yatay Açısı (Receiver Horizontal Acceptance Angle), gelen ışığın kabul edilebileceği alıcının perspektifinden yatay doğrultuda açısal kapsamdır. Daha sade bir dille alıcının yatay yöndeki kabul açısıdır. Alıcının yüzeyinden normal vektör etrafında açısal aralık simetriktir. Bu husustan dolayı, bu uygulama için "360" olarak seçilmiştir. Aşıcı Azimutal Yönü (Receiver Orientation Azimuth), alıcının azimutal yönüdür. $0=$ Kuzey, $90=$ Doğu, $270=$ Batı yönlerini ifade etmektedir. Bu model, yalnızca düz plaka alıııları için uygulanmaktadır. Alıcı En Boy Oranı (Receiver Aspect Ratio (H/W)), alıcının en boy oranını gösteren sistem tarafından otomatik olarak hesaplanan değerdir. En boy oranı, alıcının yüksekliğinin genişliğe bölünmesiyle tanımlanır; burada genişlik ile silindirik bir alıcı için belirtilen çapa eşittir. Bu değer hesaplama sonucunda sistem tarafından "2" olarak verilmiştir. Alıcı Emici Alanı (Receiver Absorber Area), Alıcının ısı emici yüzey alanıdır. Silindirik alıcılar için bu, $\pi$ değerinin yükseklik ve çap ile çarpımına eşittir. $\mathrm{Bu}$ değer sistem tarafından otomatik olarak hesaplanmakta olup, bu çalışmadaki sistem için "157,1 $\mathrm{m}^{2}$ " olarak hesaplanmıștır. 


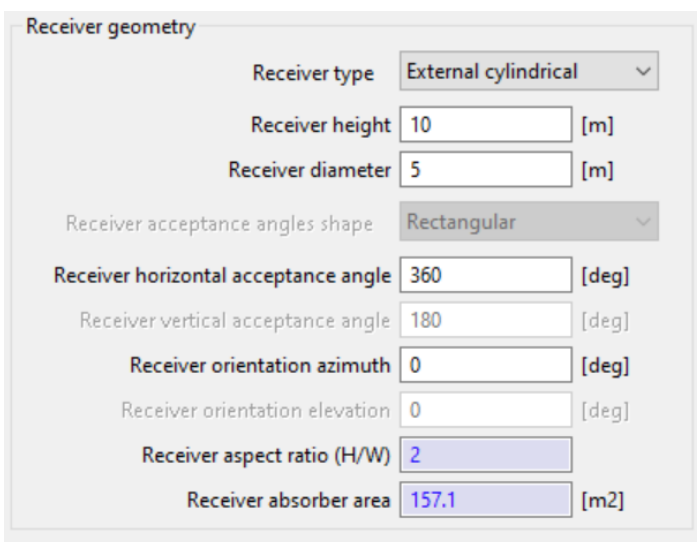

Şekil 12. Alıcı Geometrisi (Receiver Geometry)

\subsubsection{Alıcı Pozisyonu (Receiver Position)}

Bu girişleri kullanarak, alıcı konumunda kule konumuna göre bir konum belirleme imkânımız mevcuttur. Alıcı varsayılan olarak heliostat koordinatlarına göre $(x=0, y=0)$ konuma yerleştirilir.

Alıcı bütün sistemin merkezi olarak düşünülebilir. Heliostat odaklaması alıcıya yapılmakta, buradan çevrime akışkan gönderilmekte ve sistemden güç üretilmektedir. Bu husustan dolayı alıcının noktası "merkez noktası $(0,0)$ " olarak hesaplanacaktır.

\subsubsection{Alıcı Konumlandırması (Receiver Positioning Offset)}

X Ekseni alıcı konumlandırması (Receiver Positioning Offset - X Axis), alıcı konumunu Doğu-Batı yönünde konumlandırılabilir. Pozitif bir X-ofseti doğuya kaymayı göstermektedir. Y Ekseni alıcı konumlandırması (Receiver Positioning Offset - Y Axis), alıcı konumunu Kuzey-Güney yönünde konumlandırılabilir. Pozitif bir Y ofseti kuzeye kaydırmayı göstermektedir. Z Ekseni alıcı konumlandırması (Receiver Positioning Offset - Z Axis), alıcı konumunu dikey yönde konumlandırılabilir. Pozitif bir Z ofseti yukarı doğru yer değiştirmeyi göstermektedir. Uygulama merkezi olarak alıcının bulunmasından dolayı koordinatları " $(0,0,0)$ " olarak konumlandırılması uygulama için tercih edilmiştir (Şekil 13.).

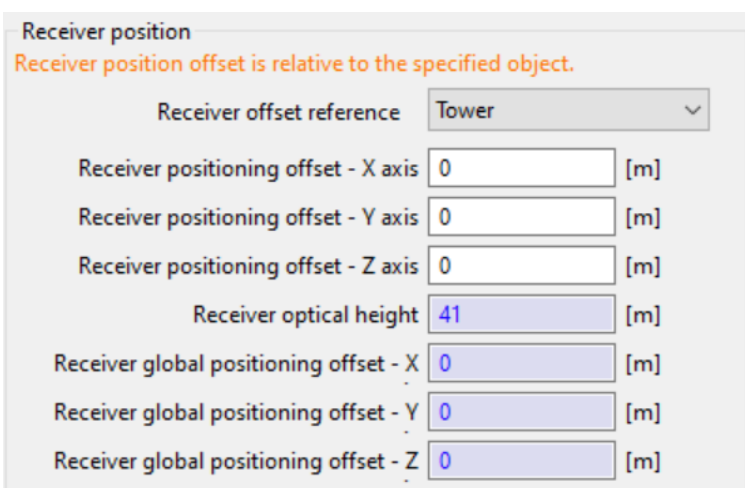

Şekil 13. Alıcı Konumlandırması (Receiver Positioning Offset)

\subsubsection{Alıcı Optik Yüksekliği (Receiver Optical Height)}

Alıcı, Z ekseni konumu dâhil, optik yüksekliğinin hesaplanmasını sağlayan değerdir. Optik yükseklik, heliostat pivot noktaları ile alıcının dikey merkezi arasındaki mesafe olarak tanımlanmaktadır. Bu değer sistem için “41m"'dir (Şekil 13.).

\subsubsection{Optik Özellikler (Optical Properties)}

\subsubsection{Alıcı Termal Emilimi (Receiver Thermal Absorptance)}

Alıcı termal emilimi, alıcıya çarparken emilen ışığın fraksiyonunu (radyasyon ve konvektif kayıplardan önce) belirtir. Bu değer tipik olarak alıcı yüzey kaplamasının emiciliğini göstermektedir. 
Alıcı emiciliği; (Wang vd., 2020), 0,9, (Wagner ve Wendelin, 2018), 0,94, (Mehos vd., 2017), güncel malzeme teknoloji sayesinde emiciliğin 0,9'dan fazla olacağını tespit etmişlerdir. Uygulama için “ 0,9 ” emicilik değerinin kullanılması tercih edilmiştir.

\subsubsection{2. İzin Verilen Tepe Akısı (Allowable Peak Flux)}

İzin verilen tepe akısı sadece optimizasyon için kullanılır. Bu değer, alıcı yüzeyinin herhangi bir noktasında izin verilen maksimum akıyı belirtir. Optimizasyon sırasında, izin verilen akı aşılırsa, algoritma alıcı yüzey alanını artırmaya çalışabilir. Uygulama için, "1000 kW/ $\mathrm{m}^{2}$ " değerinin kullanılması tercih edilmiştir.

\subsubsection{Termal Kayıplar (Thermal Losses)}

Alıcı termal kayıpları, alıcının emici yüzeyinden konvektif, radyasyon ve boru kaybını içerir. Termal kayıplar, belirtilen bir tasarım noktası değeri, alıcı emme alanı ve termal kayıpları olay güç seviyesi ve rüzgâr hızı ile ölçeklendiren polinomlar kullanılarak değerlendirme gerçekleştirilmektedir (NREL, 2018).

Termal kayıplar iki şekilde kullanılır: İlk olarak, alıcıya iletilen toplam termal gücün, güneş alanı tasarım gücüne ekstradan tasarım noktası termal kaybına ve alıcı termal emme fraksiyonundan kaynaklanan fraksiyonel kayıplara eșit olmalıdır. Bu nedenle, heliostat alan tarafından alıcıya gönderilen termal güç, tasarlanan üretim gücünden fazla olacaktır (NREL, 2018).

\subsubsection{Tasarım Noktası Alıcı Termal Kaybı (Design Point Receiver Thermal Loss)}

Bu katsayıyı kullanarak temel alıcı termal kaybını ayarlayabilirsiniz. Değer, alıcı emici alanının metrekaresi başına kWt cinsinden konveksiyon ve radyasyon nedeniyle alıcıdan kaynaklanan kayıpları gösterir. (Xu vd., 2011) yaptığı araştırmalarda alıcı termal verimliliğin \%90, (Christian ve Ho, 2012) ise termal verimliliği \%88 ile \%90,08 arasında olduğunu belirlemiștir. Uygulama için “\%90” termal verim değeri kullanılması kabul edilmiştir. Bu değer sistemden $1 \mathrm{MW}$ 'lık bir kayba sebep olmaktadır.

\subsubsection{Yüke Dayalı Termal Kayıp (Load-Based Thermal Loss Adjustment)}

Yüke dayalı termal kayıp ayarı, termal kayıpların alıcıdaki olay gücüyle nasıl değișebileceğinin belirlenmesini sağlamaktadır. Sağlanılan katsayılar, alıcıdaki güç olayı tarafından herhangi bir zamanda tasarım noktasında alıcı üzerindeki güce bölünmesiyle verilen 3. derece polinomuna karşllık gelmektedir. 0. derece katsayısı sabittir, 1 . derece katsayısı doğrusal bir terimdir, 2. derece katsayısı ikinci dereceden bir terimdir ve üçüncü derece katsayısı kübik bir terimdir. Sabit katsayı değeri sistem tarafından “bir (1)” olarak tanımlanmıştır.

Termal kayıp ayarlamaları hem tasarımdaki termal kaybı hesaplamak hem de DNI ve heliostat alanı optik verimliliği referans koşullarından saptığında yerleşim simülasyonu sırasındaki termal kaybı hesaplamak için kullanılmaktadır.

\subsubsection{Rüzgâr Kaynaklı Termal Kayıp (Wind-Based Thermal Loss Adjustment)}

Rüzgâr tabanlı termal kayıp ayarı, termal kayıpların bir hava dosyasından ölçülen rüzgâr hızıyla nasıl değişebileceğini belirlenmesini sağlar. Bu katsayılar sabit (0), doğrusal (1), kuadratik (2) ve kübik (3) terime karşılık gelir. Katsayılar, karşılık gelen güce yükseltilen rüzgâr hızı olan argümanı çoğaltır. Sabit katsayı değeri sistem tarafından “bir (1)" olarak tanımlanmıştır (NREL, 2018).

Termal kayıp ayarları hem tasarımdaki termal kaybı hesaplamak hem de rüzgâr hızı referans koşuldan (sıfır) saptığında yerleşim simülasyonu sırasındaki termal kaybı hesaplamak için kullanılmaktadır.

\subsection{Tasarım Noktası Termal Kayıp (Design-Point Thermal Loss)}

Tasarım noktası termal kaybı, referans koşullarında radyasyon ve konveksiyondan kaynaklanan toplam termal kayıp oranıdır. Bu sistem için termal kayıp değeri olarak “1 $M W^{\prime \prime}$ hesaplaması gerçekleştirilmiştir.

\subsubsection{Alıcı Boru Kayıp Katsayısı (Receiver Piping Loss Coefficient)}

Alıcı boru tesisatı kayıp katsayısı, alıcı boru tesisatı kaybını, kule yüksekliği metre başına kWt birimi cinsinden belirler. Bu kaybı (Hekim, 2017), sistem toplam gücünün yaklaşık \%12'sinin alıcı boru tesisatı kaybı olduğunu 
hesaplamıştır. Optimum kayıp olarak hesaplama gerçekleștirmek için \%10 üzerinden hesaplanması idealdir. Bu değer, sistemde “1 $M W^{\prime \prime}$ olarak hesaplaması gerçekleştirilmiştir.

\subsubsection{Alıcı Boru Kaybı Sabiti (Receiver Piping Loss Constant)}

Alıcı boru kaybı sabiti, sabit olan ve sistem geometrisine bağlı olmayan alıcı boru tesisatından kaynaklanan termal kayıpları belirlemektedir.

\subsubsection{Alıcı Boru Kaybı (Receiver Piping Loss)}

Alıcı boru tesisatı kaybı, sabit kayıp ve kule yüksekliği ile ölçeklenen kayıp dâhil toplam alıcı boru tesisatı kaybını gösteren hesaplanmış bir değer olup, alıcı boru kayıp katsayısında sistemde gerçekleşen kayıp "1 MW" olarak tespit edilmiştir.

\section{3- Deneysel Sonuçlar (Experimental Results)}

Uygulama için veri girişleri, sisteme girildiğinde Şekil 14.'deki saha düzeni ve heliostat alan verimliliği ortaya çıkmaktadır.

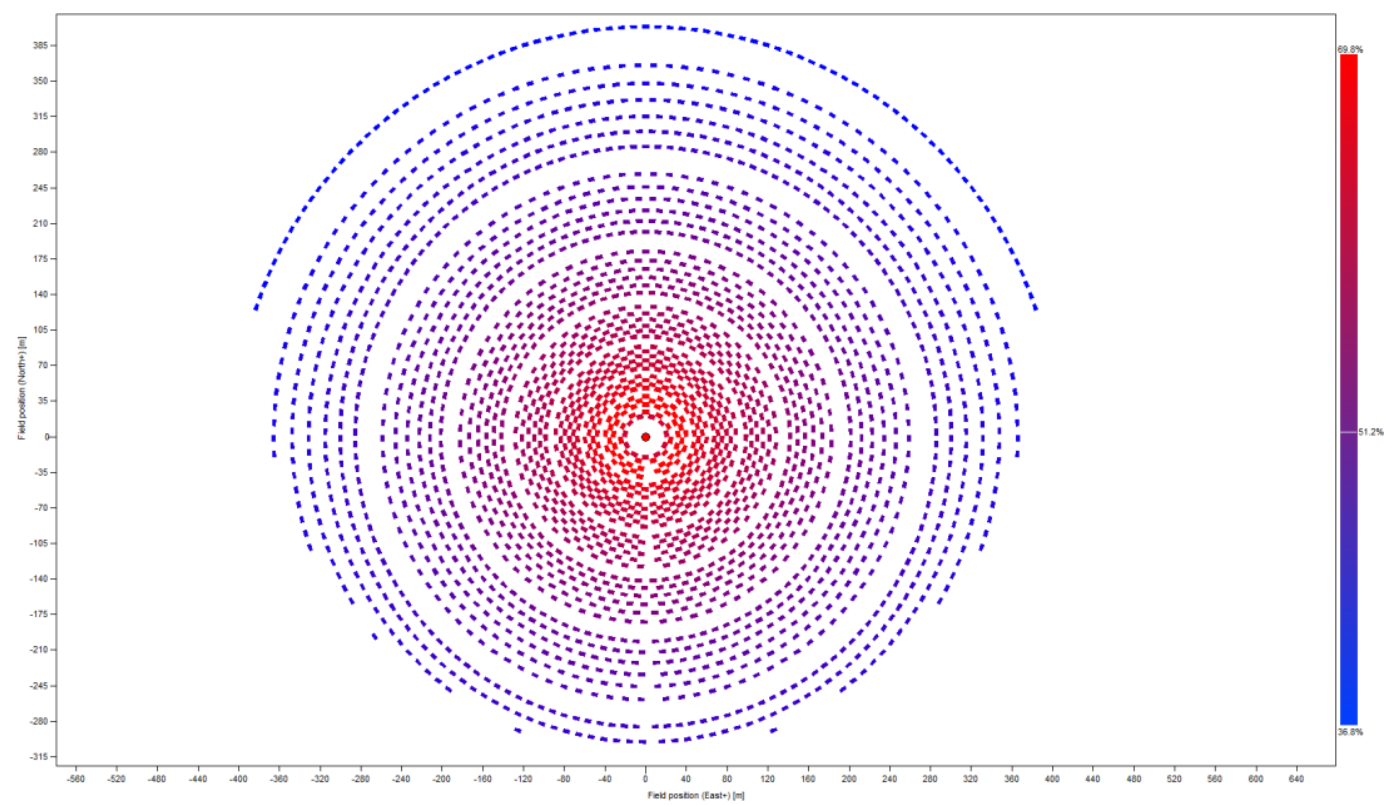

Şekil 14. Uygulama Alanı Saha Düzeni ve Heliostat Alan Verimliliği (Area of Application Layout and Heliostat Area Efficiency)

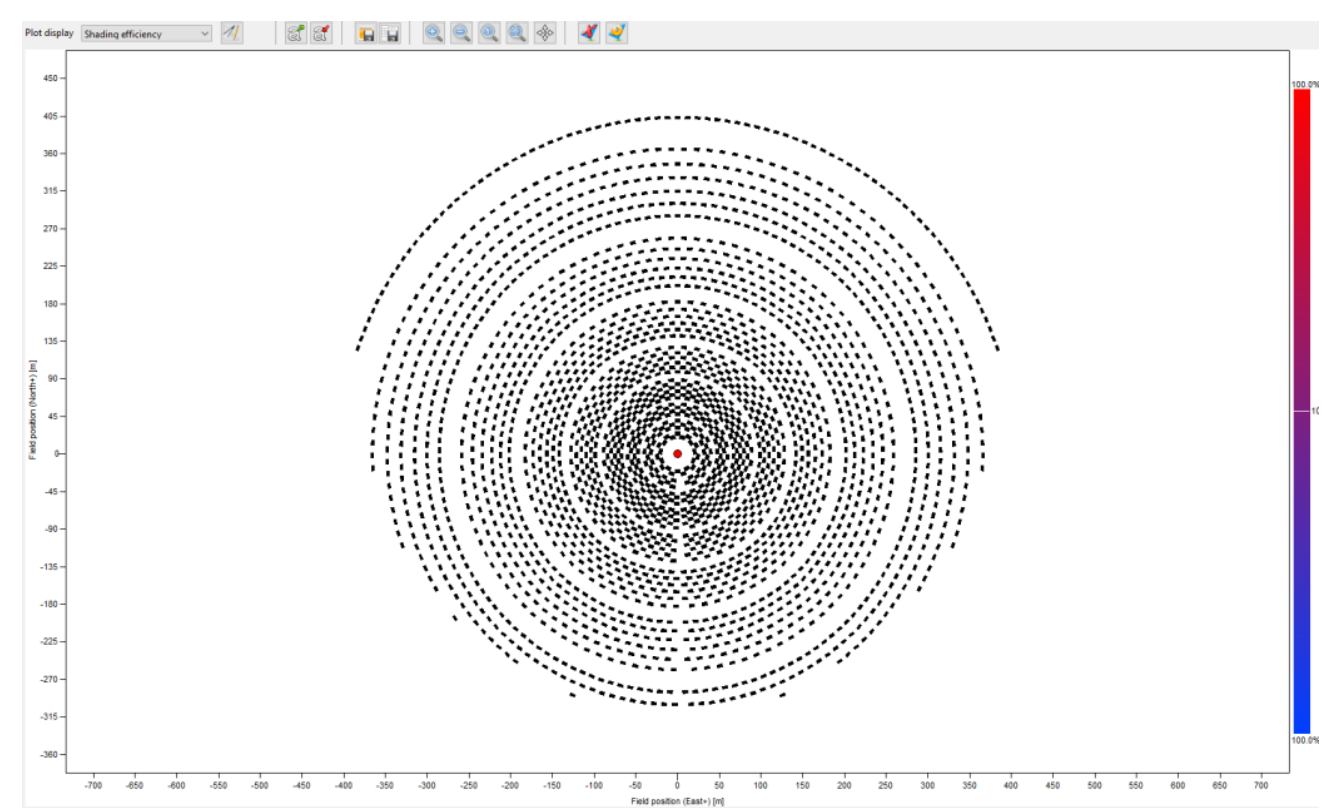

Şekil 15. Heliostatların Birbirlerini Engelleme ve Gölgelemeleri (Heliostats Blocking and Shadowing) 
Gerçekleştirilen hesaplama sonucunda, heliostat alan yerleşimine göre \%69,8 ila \%36,8 değerleri arasında verimliliği sağlanan, 2534 heliostatla gerçekleștirilen uygulama saha düzeninde (Şekil 14.), heliostat aynaların en uygun șekilde yerleștirilmesi sayesinde, aynalar birbirlerine engelleme ve gölgeleme gerçekleștirmemişlerdir (Şekil 15.).

\section{4- Sonuç ve Tartışma (Result and Discussion)}

Uygulamanın, heliostat alan yansıtma verimliliği yaklaşık \%60, alıcı termal veriminin \%90, ylllık ortalama 4,43 $\mathrm{kWh} / \mathrm{m}^{2-y l l}$ ışınım değeriyle sistem oluşturulmuştur.. Heliostatlar birbirlerine engelleme ve gölgeleme gerçekleștirmemiş olup, $60816 \mathrm{~m}^{2}$ heliostat alanıyla, uygulama alanı olarak belirlenen Süleyman Demirel Üniversitesi, Doğu Kampüsü, Teknokent yolu üzerinde bulunan alan üzerinde sistemin inşasının gerçekleştirilmesi, genel sistem verimi (Şekil 14.), (Şen, 2021) yaptı̆̆ı araştırmalarda, belirtilen verimliliklerin güneş kulesi tesis tasarımı için uygunluğunu tespit edilmiştir. Gerçekleştirilen modelleme sayesinde heliostat aynaların uygulama alanındaki koordinatları bellidir. Bu sayede, sistem inşası çok daha hızlı gerçekleștirilecektir.

Tablo 2. İncelendiğinde, Ekim, kasım, aralık, ocak, şubat ve mart aylarında ışınım değerinin hesaplama değerinden az olmasından dolayı, sistemden elde edilecek güç azalacaktır. Nisan, mayıs, haziran, temmuz, ağustos ve eylül aylarında ışınım değerinin hesaplama değerinden fazla olmasından dolayı, sistemde elde edilecek güç istenilen değerde alınacaktır. Işınım değerinin hesaplanandan fazla gelmesinden dolayı sistem maksimum verimle çalışacak olup, fazla değerin kullanılması ancak termal depolama yönetimiyle sağlanabilir.

DNI değerlerinin fazla olduğu aylarda termal depolama imkânı, sistemsel açıdan DNI değerlerinin sistemsel hesaplamada gerçekleștirilen değerden az olduğu zamanlarda kullanılarak üretilecek gücü arttırma imkânı olarak kullanılacaktır. Bu sayede üretilen güç, daimî olarak belirli bir değer aralığında olacağından, kullanım hesaplamaları daha net şekilde gerçekleştirilecektir.

Güneș enerjisi ışınım değerleri bakımından yüksek değerlerde olan alanlarda kurulumu gerçekleștirilecek $10 \mathrm{MW}$ - 15 MW güneș kulesi tesisleri bölgesel olarak elektrik ihtiyacının karşılanabilecektir. 10 MW- 100 MW ve daha üzeri güçlerde kurulacak santraller sayesinde enerji alanında dışa bağımlılığın azaltılabileceği ve güneş kulesi alanında AR-GE çalışmalarının yoğunlaşmasıyla genel verim arttırılabilecektir. Bu yöntem atmosfere zararlı emisyon salmadığından ötürü, elektrik üretimi ülkemizde aktif olarak üretim tesislerinden daha fazla çevre dostudur (Şen, 2021).

\section{Çıkar Çatışması (Conflict of Interest)}

Yazarlar tarafından herhangi bir çıkar çatışması beyan edilmemiştir. No conflict of interest was declared by the authors.

\section{Kaynakça (References)}

SAM, 2020. Erișim Tarihi:17/07/2020. https://sam.nrel.gov/

NREL, 2020. Solar Power Tower Integrated Layout and Optimization Tool. Erişim Tarihi: 17/07/2020. https://www.nrel.gov/csp/solarpilot.html

European Commission, 2019. Photovoltaic Geographical Information System. Erişim Tarihi: 23/07/2020. https://re.jrc.ec.europa.eu/pvg_tools/en/\#TMY

$\begin{array}{llll}\text { Freedictionary, } & \text { 2020, } & \text { Erişim } & \text { Tarihi: }\end{array}$ https://encyclopedia2.thefreedictionary.com/Atmospheric+Attenuation\#: :text=a\%20reduction\%20in\%20the\%20inte nsity,molecules\%20of\%20air\%20and\%20aerosols.

NREL, 2018. SolarPILOT (Sürüm 1.3.8)[Yazılım]. Denver, USA. Tedarik edilebileceği adres: https://www.nrel.gov/csp/solarpilot-download.html

Lopez, J.N.M., 2016, The inuence of irradiance concentration using an asymmetric reector on the electrical performance of a PVT hybrid collector with standard monocrystalline cells, Lizbon Üniversitesi, Enerji Mühendisliği ve Yönetimi bölümü, Yüksek Lisans tezi, 66 s., Lizbon.

Cole, I.R., Gottschalg, R., 2015. Optical modelling for concentrating photocoltaic systems: insolation transfer variations with solar source descriptions, IET Renewable Power Generation, 9(5), 413-419.

Kamada, R.F., Flocchini, R.G., Gaussian Solar Flux Model, Solar Energy, 1986,36(1), 73-87.

System Advisor Model, Overview of NREL's SolarPilot(TM) and SolTrace Open-source Softwate(video dosyası) Erişim Tarihi:26/07/2020 https://www.youtube.com/watch?v=wiYV2VLqr_k

Ramadevi, M.C., Limb Darkening, Erişim Tarihi: 25/07/2020 http://www.iucaa.in/ dipankar/ph217/contrib/limb.pdf

Wang, Y., Potter, D., Asselineau, C.A., Corsi, C., Wagner, M., Caliot, C., Piaud, B., Blanco, M., Kim, J.S., Pye, J.,Verification of optical modelling of sunshape and surface slope error for concentrating solar power systems, 2020, Solar Energy 195 (2020) 461474. 
Bird, R., Hulstrom, R.L., 1980, Direct Insolation Models, Erişim Tarihi: 26/07/2020 https://www.nrel.gov/docs/legosti/old/344.pdf

Hanrieder, N., Sengupta, M., Xie, Y., Wilbert, S., Paal, R.P., Modeling beam attenuation in solar tower plants using common DNI measurements, Solar Energy, 2016, 129, 244-255.

SAND2008-8053, 2008. Software and Codes for Analysis of Concentrating Solar Power Technologies. Sandia Ulusal Laboratuvarları. Kaliforniya.

Bouamra, M., Merzouk, M., 2019, Cosine Efficiency Distribution with Reduced Tower Shadowing Effect in Rotating Heliostat Field, Arabian Journal for Science and Engineering, 44, 1415-1424.

EIGM, 2020, Erişim Tarihi: 07/09/2020. http://www.yegm.gov.tr/MyCalculator/pages/32.aspx

Wikipedia, Yaz Gündönümü. Erișim Tarih https://tr.wikipedia.org/wiki/Yaz_g\%C3\%BCnd\%C3\%B6n\%C3\%BCm\%C3\%BC

Sarıgül, T., 2018, Ekinoks Nedir? Erişim Tarihi:28/07/2020. http://bilimgenc.tubitak.gov.tr/makale/ekinoks- nedir

Wikipedia Ekinoks. Erişim Tarihi:01/09/2020. https://tr.wikipedia.org/wiki/Ekinoks

Wikipedia Kış Gündönümü. Erişim https://tr.wikipedia.org/wiki/K\%C4\%B1\%C5\%9F_g\%C3\%BCnd\%C3\%B6n\%C3\%BCm\%C3\%BC

Ceylan. İ., Gürel. E., 2017, Güneş Enerjisi Sistemleri ve Tasarımı. Dora yayınevi, 196s, Bursa.

European Commission, 2020, Report on Best Available Technologies (BAT) for central receiver systems. 221766, 70.

Gadalla, M., Saghafifar, M., 2018, A concise overview of heliostat fields-solar thermal collectors: Current state of art and future perspective, International Journal Of Energy Research, 3145- 3163.

Arrif, T., Benchabane, A., Germoui, M., Bezza, B., Belaid. A., 2018. Optimisation of heliostat field layout for solar power tower systems using iterative artificial bee colony algorithm: a review and case study. Erişim Tarihi: 29/07/2020. https://www.tandfonline.com/doi/full/10.1080/01430750.2018.1525581

Siala, F.M.F., Elayeb, M.E., Mathematical formulation of a graphical method for a no-blocking heliostat field layout,2001, Yenilenebilir Enerji, 23,77-92.

Mehos, M., Turchi, C., Vidal, J, Wagner, M., Ma, Z., Ho, C., Kolb, W., Andraka, C., Kruzenga, A., 2017, Concentrating Solar Power Gen3 Demonstration Roadmap. NREL/TP-5500-67464, 127.

Wagner, M.J., Wendelin, T., 2018, SolarPILOT: A power tower solar field layout and characterization tool, Solar Energy, 171, 185-196.

Qiu, Y., He, Y. L., Li, P., Du, B. C., A comprehensive model for analysis of real-time optical performance of a solar power tower with a multi-tube cavity receiver Erişim Tarihi: 07/08/2020. https://hal.archives-ouvertes.fr/hal-01344014v3

Khalsa, S.S.S., Ho, C.K., Andraka, C.E., An Automated Method To Correct Heliostat Tracking Racking Errors, Erişim Tarihi:07/08/2020. https://www.osti.gov/servlets/purl/1106781

Andraka, C.E., 2008. Cost/Performance Tradeoffs For Reflectors Used In Solar Concentrating Dish Systems. Erișim Tarihi: 08/08/2020. https://energy.sandia.gov/wp-content/gallery/uploads/Cost-performance_Tradeoffs.pdf

Leea, H.J., Kimb, J.K., Leeb, S.N., Yoonb, H.K., Kangb, Y.H., Parkc, M.H., 2015, Calculation of optical efficiency for the first centralreceiver solar concentrator system in Korea, Energy Procedia, 69, 126 - 131

Göttsche, J., Lampkowski, M., Bezerra, P.H.S., Teramoto, É.T., Boura, C.T., 2017. A Method For Calculating The Slope Error Of Mirrored Surfaces Consisted Of Facets Curved In One Axis Used In Concentrated Solar Power (CSP) Tower Systems. Erişim Tarihi:08/08/2020. http://energia.fca.unesp.br/index.php/energia/article/view/2271

González, A.S., 2016, Heliostat field aiming strategies for solar central receivers, Carlos III de Madrid Üniversitesi, Termal ve Akıșkan Mühendisliği Bölümü, Doktora tezi, 104s., Madrid.

Hekim, M., 2017, Merkezi Alıcı Sistemli(MAS) Güneș Güç Santrali Birecik Uygulaması, Hacettepe Üniversitesi, Fen Bilimleri Enstitüsü, Yüksek Lisans Tezi, 137s., Ankara.

Bonanos, A.M., 2012, Error analysis for concentrated solar collectors, Renewable Sustainable Energy, 4,1-11.

Xu, E., Yu, Q., Wang, Z., Yang, C., 2011, Modeling and simulation of 1 MW DAHAN solar thermal power tower plant, Renewable Energy, 36, 848-587.

Christian, J.M., Ho, C.K., 2012, CFD simularion and heat loss analysis of the solar two power tower receiver, Proceedings of ASME 2012, 23-26 temmuz, San Diego, 1-9.

Şen, S., 2021, Tepe Heliostat Alanlı Güneş Kulesi Uygulamaları, Süleyman Demirel Üniversitesi, Fen Bilimleri Enstitüsü, Yüksek Lisans Tezi, 112s, Isparta, 